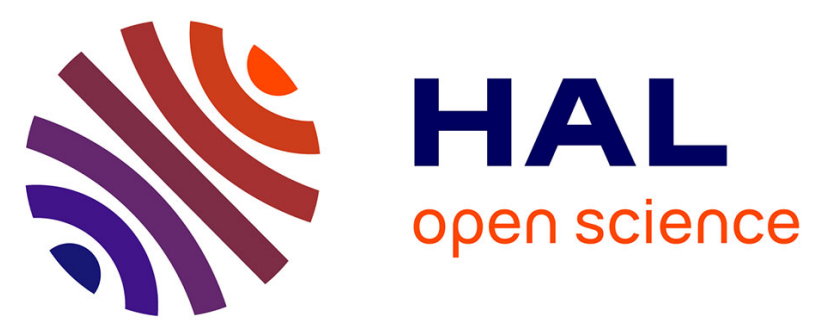

\title{
Discovery and Hit to Lead Optimization of Novel Combretastatin A-4 Analogues: Dependence of C-Linker Length and Hybridization
}

Olivier Provot, Abdallah Hamze, Jean-François Peyrat, Jean-Daniel Brion, Mouad Alami

\section{To cite this version:}

Olivier Provot, Abdallah Hamze, Jean-François Peyrat, Jean-Daniel Brion, Mouad Alami. Discovery and Hit to Lead Optimization of Novel Combretastatin A-4 Analogues: Dependence of C-Linker Length and Hybridization. Anti-Cancer Agents in Medicinal Chemistry, 2013, 13 (10), pp.1614-1635. 10.2174/187152061310131206162302 . hal-02394384

\section{HAL Id: hal-02394384 \\ https://hal.science/hal-02394384}

Submitted on 4 Dec 2019

HAL is a multi-disciplinary open access archive for the deposit and dissemination of scientific research documents, whether they are published or not. The documents may come from teaching and research institutions in France or abroad, or from public or private research centers.
L'archive ouverte pluridisciplinaire HAL, est destinée au dépôt et à la diffusion de documents scientifiques de niveau recherche, publiés ou non, émanant des établissements d'enseignement et de recherche français ou étrangers, des laboratoires publics ou privés. 


\section{Discovery and hit to lead optimization of novel Combretastatin A-4}

\section{analogues: dependence of $\mathrm{C}$-linker length and hybridization}

Olivier Provot,*Abdallah Hamze, Jean-François Peyrat, Jean-Daniel Brion and Mouad

Alami*

Univ. Paris-Sud 11, CNRS, BioCIS-UMR 8076, LabEx LERMIT, Laboratoire de Chimie Thérapeutique, Faculté de Pharmacie, 5 rue J.-B. Clément, Châtenay-Malabry, F-92296, France.

\footnotetext{
*Corresponding author

E.mail: olivier.provot@u-psud.fr or mouad.alami@u-psud.fr

Phone: O.P. (+33) 146835847 or M.A. (+33) 146835887.
}

Fax: (+33) 146835828 


\section{Abstract:}

We have synthesized a large variety of CA-4 analogues having a non-isomerizable C-linker between the A- and B-aromatic rings. Most of them displayed a nanomolar level of cytotoxicity against a panel of human cancer cell lines and inhibited tubulin polymerization at a micromolar level. Among all these compounds, the most interesting compounds were undoubtedly isoCA-4 and structural analogues 18-20 as well as benzil derivatives $\mathbf{1 1}$ which displayed a comparable level of activity than that of CA-4. Moreover, it has been demonstrated that these drugs arrested cancer cells in the $G_{2} / M$ phase of cellular cycle and induced apoptosis at very low concentrations. In vitro antivascular effects and the binding mode of the most active compounds was also investigated.

Key words: Combretastatin A-4, isoCA-4, cytotoxicity, tubulin, linker, apoptosis, binding.

\section{Introduction:}

Combretastatin A-4 (CA-4, Figure 1) 1, a natural product originally isolated from the bark of the South African bush willow tree Combretum caffrum by Pettit in 1989 [1] exhibits strong antitubulin activity ( IC $_{50}$ at a micromolar level) by binding to the colchicine binding-site of tubulin. [2,3] CA-4 also exerts a highly potent cytotoxicity $\left(\mathrm{GI}_{50}\right.$ at a nanomolar level) against a variety of human cancer cells including multidrug resistant (MDR) cancer cell lines. [4] More importantly, CA-4 displays selective cytotoxicity toward tumour vessels by inhibiting the blood supply to the tumor, leading to cell death. [5] The major problems associated with this molecule were poor aqueous solubility [6,7] and isomerization of the Z-alkene into the more stable but inactive $E$-isomer during storage, administration and metabolism. [8-10] The solubility problem was solved by the synthesis of the water-soluble phosphate CA-4P 2 and amino-serine AVE8062 3 prodrugs which cause a rapid and extensive vascular shutdown in experimental tumor models. [11-13] CA-4P which has been developed by Oxigene Inc., in USA, is currently used for the treatment of thyroid cancers. [14] However, despite the efficiency of CA-4P, cardiovascular toxicity and neurotoxicity were doselimiting for this molecule. [15] These drawbacks and the structural simplicity of CA-4 stimulate the search for new and more potent compounds with improved pharmacological properties. [16]

Figure 1. CA-4, its water-soluble prodrugs and structure activity relationships (SAR).<smiles>COc1ccc(/C=C\c2cc(OC)c(OC)c(OC)c2)cc1O</smiles>

CA-4 1

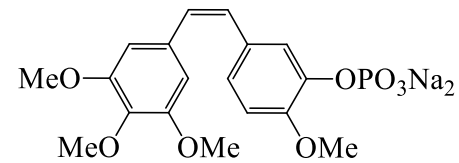

CA-4P 2

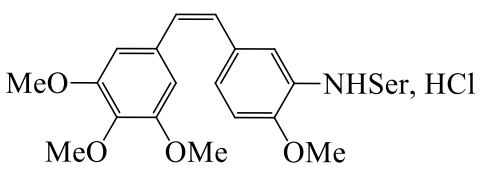

AVE8062 3

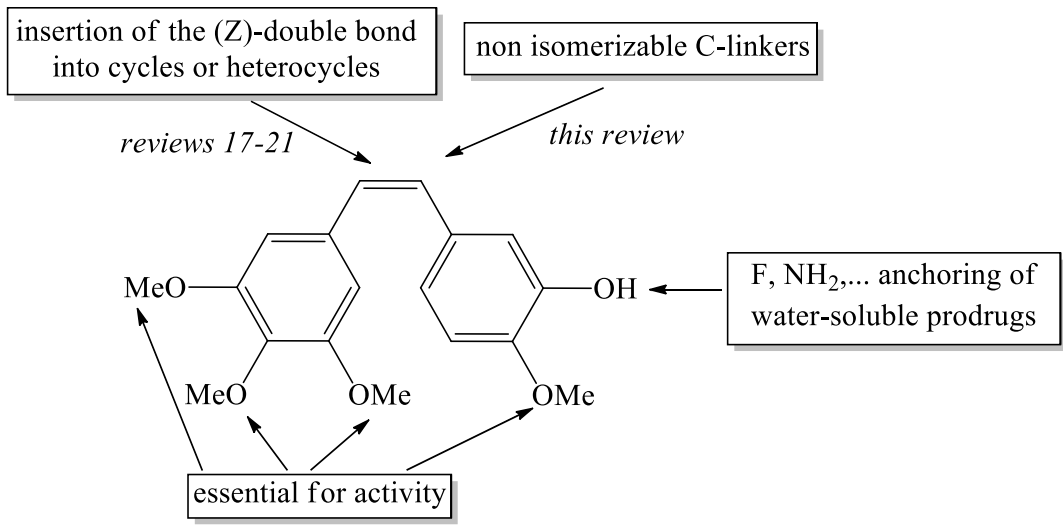

To avoid instability problems associated with the isomerization of the double bond, considerable effort has been done into modifying the $Z$-alkene double bond, most of the time by insertion of the CA-4 double bond in rings [17-21]. Others medicinal groups have attempted to replace the Z-double bond by linkers of different sizes, containing or not heteroatoms in their structure to increase the biological properties of such analogues. [22, 23] 
This review will summarize our contribution since 2008, in acyclic linker modifications, with compounds having a six, four, two and one carbon atoms linker between the aromatic rings. The synthesis of such analogues will be presented and in vitro biological results, including cytotoxicity and inhibition of tubulin polymerization will be discussed in comparison to CA-4, as the reference. [24] After evaluation of cytotoxicity and antitubulin properties, the most potent derivatives will be considered for further

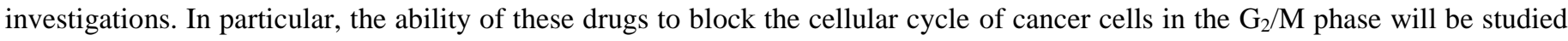
and their apoptotic properties will be examined. The binding mode of selected drugs, able to occupy the colchicine-binding site, will be compared to CA-4 at the end of the manuscript.

\section{Synthesis and biological evaluation of CA-4 analogues with aromatic rings joined by $\mathrm{C}$-acyclic linkers of varying length and hybridization.}

\subsection{C6-linker: enediynes 4.}

2.1.1 Synthesis. In order to preserve the (Z)-stereochemistry of the CA-4 stilbene double bond and to maintain the $\pi$-conjugated system, we first prepared a series of CA-4 analogues incorporating between the double bond and the aromatics two triple bonds. [25] Moreover, such analogues, having a enediyne moiety in their structure could benefit from this pharmacophore found in many anticancer agents, as for example the calicheamicin, esperamicin and dynemicin families. [26]

Scheme 1. ${ }^{a}$ Synthesis of $(Z)$-enediynes 4 a-d.

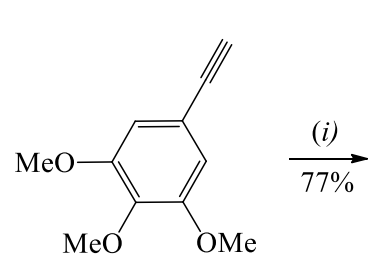

5

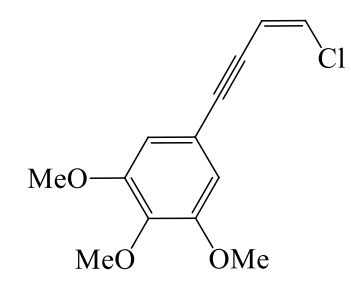

6

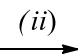

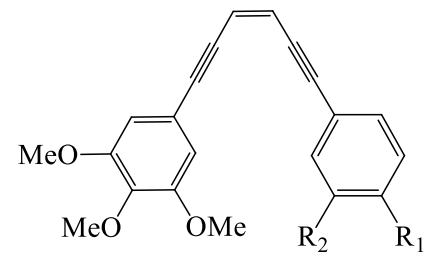

4a $\mathrm{R}^{1}=\mathrm{OMe}, \mathrm{R}^{2}=\mathrm{H} \quad 86 \%$

$4 \mathbf{b} \mathrm{R}^{1}-\mathrm{R}^{2}=-(\mathrm{CH})_{4^{-}} \quad 71 \%$

4c $\mathrm{R}^{1}=\mathrm{OMe}, \mathrm{R}^{2}=\mathrm{OH} \quad 73 \%$

$4 \mathbf{d ~} \mathrm{R}^{1}=\mathrm{OMe}, \mathrm{R}^{2}=\mathrm{NH}_{2} \quad 61 \%$

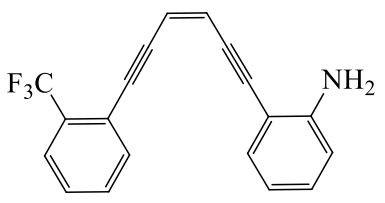

$7[33]$

${ }^{a}$ Reagents and conditions: (i) $\mathrm{PdCl}_{2}\left(\mathrm{PPh}_{3}\right)_{2}(5 \mathrm{~mol} \%), \mathrm{CuI}(10 \mathrm{~mol} \%),(\mathrm{Z})-1,2$-dichloroethylene (2 equiv), $n$ - $\mathrm{BuNH}_{2}(2 \mathrm{equiv}), \mathrm{Et}_{2} \mathrm{O}, 20{ }^{\circ} \mathrm{C} .($ ii $)$ $\mathrm{PdCl}_{2}(\mathrm{PhCN})_{2}(5 \mathrm{~mol} \%)$, CuI (10 mol\%), alkyne (1.2 equiv), piperidine.

Enediynes 4a-d (Scheme 1) were synthesized in two steps from alkyne 5 readily prepared according to literature. [27, 28] A first Pd-coupling reaction between 5 and (Z)-1,2-dichloroethylene furnished the isomerically pure Z-chloroenyne 6 in 77\% yield. [29] Based on previous work with this class of not photosensitive compounds, we showed that the $\mathrm{C}$ - $\mathrm{Cl}$ bond is not inert to further coupling reactions with terminal alkynes. $[30,31]$ As expected, $(Z)$-chloroenyne 6 reacted cleanly with a selection of terminal alkynes to afford stereoselectively the desired $(Z)$-enediynes $\mathbf{4 a - d}$.

2.1.2 Biological results. Enediynes 4a-d were evaluated for their cytotoxic effects against K562 (human cervical carcinoma), MCF7 (human breast adenocarcinoma), MCF7R (multidrug resistant human breast cancer) cells and for tubulin polymerization inhibitory activities. However most of enediynes were poorly cytotoxic $\left(\mathrm{GI}_{50}>1000 \mathrm{nM}\right)$ against the three tested cell lines. Enediyne 4d, having the greatest resemblance to AVE8062 3, inhibited the tubulin polymerization $\left(\mathrm{IC}_{50}=68 \mu \mathrm{M}\right)$ but was almost 50 -fold less active on tubulin than CA-4. One note that Wu described the synthesis of another series of $(Z)$-enediynes having various substituents on both aromatic rings. [32] Among the synthesized compounds, aniline 7 having ortho-substituents on aromatic rings displayed interesting anticancer properties with $\mathrm{GI}_{50}$ of $10^{-7}-10^{-6} \mathrm{M}$ against various cancer cell lines and inhibited tubulin polymerization with an $\mathrm{IC}_{50}$ value of $10 \mu \mathrm{M}$. In the enediynes series, examination of the biological results revealed that the incorporation of two triple bonds does not play a role for maximal anticancer properties. Then, we decided to examine the role on biology of the incorporation of a single triple bond between both aromatic rings and the Z-double bond by preparing a series of (Z)-enynes having a C4-linker.

\subsection{C4-linker: $(Z)$-enynes 8 and 9.}


2.2.1 Synthesis. Enynes 8a-c having a triple bond between the 3,4,5-trimethoxyphenyl A-ring and the Z-double bond were easily prepared from (Z)-chloroenyne 6 whereas enynes 9a-c having the triple bond between the B-ring and the stilbene moiety were synthesized from (Z)-chloroenynes 10a-c. [30] In the presence of $\mathrm{Et}_{3} \mathrm{~N}$ and a catalytic amount of $\mathrm{PdCl}_{2}\left(\mathrm{PPh}_{3}\right)_{2}$, $(Z)$-chloroenynes 6 and 10a-c undergo rapid coupling with Grignard reagents [33-36] to afford stereoselectively the required enynes derivatives in good yields (Scheme 2).

Scheme 2. ${ }^{a}$ Synthesis of enynes 8a-c and 9a-c.

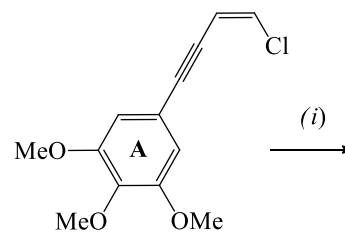

6

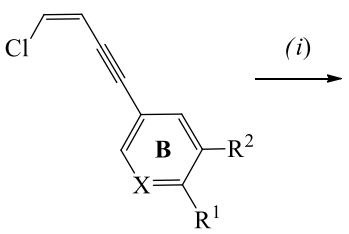

10a-c

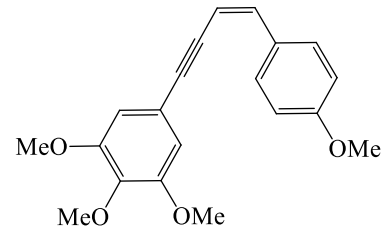

8a $(56 \%)$

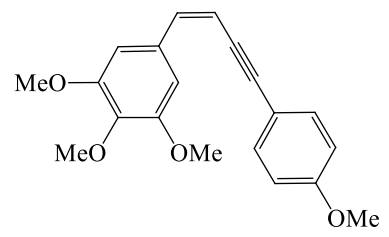

9a $(61 \%)$

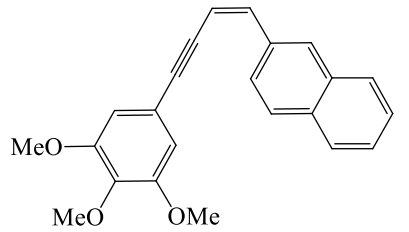

$8 \mathbf{b}(64 \%)$

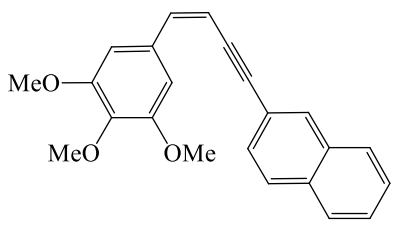

9b $(51 \%)$

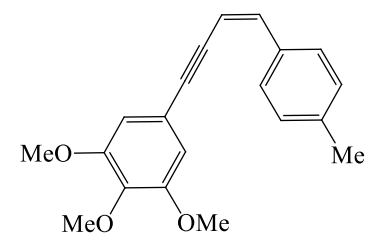

8c $(93 \%)$

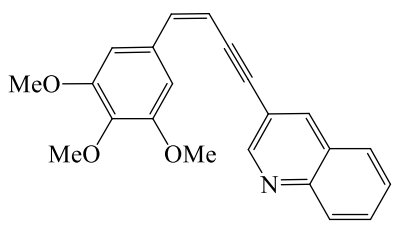

9c $(77 \%)$

${ }^{a}$ Reagents and conditions: (i) $\mathrm{ArMgBr}$ (2 equiv), $\mathrm{PdCl}_{2}\left(\mathrm{PPh}_{3}\right)_{2}(5 \mathrm{~mol} \%), \mathrm{Et}_{3} \mathrm{~N}$ (8 equiv), THF, rt.

2.2.2 Biological results. Enynes 8 and 9 were not cytotoxic $\left(\mathrm{GI}_{50}>1000 \mathrm{nM}\right)$ and did no inhibit significantly tubulin polymerization $\left(\mathrm{IC}_{50}>65 \mu \mathrm{M}\right)$. These results suggested that the insertion of a triple bond between the stilbene moiety and both $\mathrm{A}$ or B-rings is not acceptable for a potent anticancer activity. One can note that contrary to enynes $\mathbf{8}$ and $\mathbf{9}$, vinylogous CA-4 derivatives having an additional $(E)$-double bond between the A- or B-rings and the stilbene moiety [37] inhibited tubulin assembly at concentrations comparable or lower to that of CA-4.

\subsection{C2-linker: benzil derivatives 11.}

It has been demonstrated, that phenstatin 12 [38-40] and chalcone 13, [41-43] where the ethylene bridge of CA-4 was replaced by a carbonyl or a propenone function respectively, showed excellent antiproliferative and antitubulin properties (Figure 2).

Figure 2. Cytotoxicity against P388 (leukemia) cells and ITP of phenstatin $\mathbf{1 2}$ and chalcone $\mathbf{1 3}$.<smiles>COc1ccc(C(=O)c2cc(OC)c(OC)c(OC)c2)cc1O</smiles>

Phenstatin 12 C1-linker

$\mathrm{GI}_{50} / \mathrm{GI}_{50} \mathrm{CA}-4 \mathrm{P}=8$

ITP: $\mathrm{IC}_{50} / \mathrm{IC}_{50} \mathrm{CA}-4=0.9$

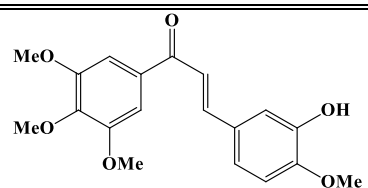

Chalcone 13 C3-linker

$\mathrm{GI}_{50} / \mathrm{GI}_{50} \mathrm{CA}-4=9$

ITP: $\mathrm{IC}_{50} / \mathrm{IC}_{50} \mathrm{CA}-4=0.9$

With this idea in mind, we next focused our attention on the preparation of benzil derivatives $\mathbf{1 1}$ having two keto-groups as C2linker which could be seen as hybrids of CA-4 and phenstatin 12.

2.3.1 Synthesis. To this end, we have investigated the oxidation of various diarylalkynes with DMSO in the presence of catalytic amounts of transition-metal salts. We found that a variety of metal catalysts including, $\mathrm{CuBr}, \mathrm{InCl}_{3}, \mathrm{MnBr}_{2} \mathrm{were}$ effective to achieve this transformation. Among them, $\mathrm{FeBr}_{3}$ holds certain supremacy and was used to successfully oxidize various diarylalkynes into benzil derivatives in DMSO under microwave irradiation. [44] However, under these conditions, phenol- or aniline-containing diarylalkynes were not transformed effectively into the required benzils. This difficulty was solved by replacing 
$\mathrm{FeBr}_{3}$ by $\mathrm{PdI}_{2}[45]$ and thus a series of benzil derivatives 11 was prepared by this way at $140^{\circ} \mathrm{C}$ under a classical heating (Figure 3).

Figure 3. Synthesis, cytotoxicity and inhibition of tubulin polymerization (ITP) of selected benzils 11a-d.<smiles>COc1cc(C(=O)C(=O)c2cc(OC)c(OC)c(OC)c2)cc(OC)c1OC</smiles>

\begin{tabular}{|c|c|c|c|c|c|c|}
\hline & \multirow[t]{2}{*}{ Compounds } & \multicolumn{4}{|c|}{ Cytotoxicity $\mathrm{GI}_{50}(\mathrm{nM})^{a}$} & \multirow[t]{2}{*}{$\operatorname{ITP}_{\mathrm{IC}_{50}}(\mu \mathrm{M})^{b}$} \\
\hline & & HCT116 & K562 & H1299 & MDA-MB231 & \\
\hline $11 a$ & & 300 & - & - & - & 21 \\
\hline $11 b$ & & 40 & 25 & 30 & 40 & $\mathrm{NA}^{\mathrm{c}}$ \\
\hline 11c & & 35 & 25 & 30 & 40 & 1.5 \\
\hline \multirow[t]{2}{*}{ 11d } & & 38 & 20 & 50 & 30 & 5.0 \\
\hline & CA-4 & 1.8 & 3.6 & 5.0 & 3.0 & 1.0 \\
\hline
\end{tabular}

$\overline{\bar{a}} \mathrm{GI}_{50}$ is the concentration of compound needed to reduce cell growth by $50 \%$ following cell treatment with the tested drug (average of three experiments). ${ }^{b}$ ITP, Inhibition of Tubulin Polymerization; IC $_{50}$ is the concentration of compound required to inhibit $50 \%$ of the rate of microtubule assembly (average of three experiments). ${ }^{c}$ Not active.

\subsubsection{Biological results. [46]}

2.3.2.1 Antiproliferative activity. Diketones 11c and 11d having the greatest resemblance to CA-4 and AVE8062 as well as acetate 11b showed potent nanomolar activity with $\mathrm{GI}_{50}$ values ranging from 35 to $40 \mathrm{nM}$ in $\mathrm{HCT} 116$ cancer cell lines $\left(\mathrm{GI}_{50} \mathrm{CA}_{-4}\right.$ $=1.8 \mathrm{nM})$. These 1,2-diketones, except 11a which displayed a lower level of cytotoxicity against HCT116 $\left(\mathrm{GI}_{50}=300 \mathrm{nM}\right)$ cells, were next evaluated in K562 (chronic mylogenous leukemia), H1299 (non small lung human carcinoma) and MDA-MB-231 (human breast cancer) cell lines. Again, these compounds were found to be very effective with GI 50 values ranging from 20 to 50 $\mathrm{nM}$ which are comparable to that observed in the HCT116 cell line (Figure 3).

2.3.2.2 Antitubulin activity. Benzils 11 were next evaluated for their ability to inhibit tubulin polymerization. The results indicated that the benzil's antiproliferative activity correlated with the inhibition of tubulin assembly. Compounds 11c and 11d were efficacious in inhibiting tubulin assembly, with $\mathrm{IC}_{50}$ values of 1.5 and $5.0 \mu \mathrm{M}$, respectively, comparable to that of CA-4 $\left(\mathrm{IC}_{50}=1.0 \mu \mathrm{M}\right)$. One can note that, in the absence of esterases in the tubulin assay, the cytotoxic acetate prodrug $11 \mathbf{b}$ was not transformed into its phenolic active form (see 11c for comparison) and was found to be inactive on tubulin. 
2.3.2.3 Effects on cell cycle distribution and apoptosis. Because molecules exhibiting activity on tubulin binding should cause the alteration of cell cycle parameters leading to a preferential $\mathrm{G}_{2} / \mathrm{M}$ blockade, $[16,47,48]$ the effect of 11c and 11d on cell cycle distribution was analyzed in HCT116 and H1299 cells cultured for $24 \mathrm{~h}$ at different concentrations. As shown in Table 1, a

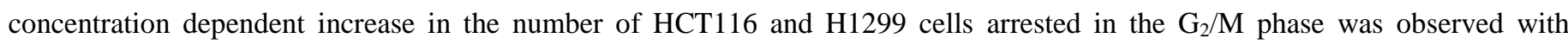
compounds 11c and 11d. It should be noted that in all cells treated with diketones 11c and 11d for 24 h, a sub-diploid DNA content was observed (data not shown) indicating that cells are undergoing apoptosis probably as a result of the cell cycle being arrested in the $\mathrm{G}_{2} / \mathrm{M}$ phase.

Table 1. Flow cytometry analysis of compounds 11c and 11d in HCT116 and H1299 cancer cells ${ }^{a}$

\begin{tabular}{cccc}
\hline \hline Benzil & $\begin{array}{c}\text { Concentration } \\
(\mathrm{nM})\end{array}$ & $\begin{array}{c}\text { HCT116 } \\
\left(\% \mathrm{G}_{2} / \mathrm{M}\right)\end{array}$ & $\begin{array}{c}\mathrm{H} 1299 \\
\left(\% \mathrm{G}_{2} / \mathrm{M}\right)\end{array}$ \\
\hline \hline DMSO & - & 11.5 & 8.4 \\
11c & 10 & 11 & 11.4 \\
& 20 & 18.5 & 15 \\
& 50 & 22.8 & 27.7 \\
11d & 10 & 13 & 11.7 \\
& 20 & 15.9 & 12.2 \\
& 50 & 28 & 16.5 \\
\hline
\end{tabular}

$\overline{\bar{a} \text { Data represent percentage of cells in } \mathrm{G}_{2} / \mathrm{M} \text { phase of the cell cycle }}$ after $24 \mathrm{~h}$ of treatment with 11c and 11d. Data are representative of three independent experiments.

Therefore, the effect of diketones 11c and 11d at different concentrations (5, 50, $100 \mathrm{nM})$ on apoptosis induction in H1299 cells was studied using caspases -3 and -7 standard assays. [49] The enzymatic activity of both caspases was measured by monitoring the cleavage of Z-DEVD-R110, a fluorogenic substrate, in cancer cell lines. The results presented in Figure 4, show a significant concentration-dependent increase in proteolytic activity of caspases in the cells treated for $48 \mathrm{~h}$ with diketones 11c and 11d. There is a marked effect in apoptosis in H1299 cells using 11c or 11d at a low concentration of $50 \mathrm{nM}$. Taken together, the biological results suggested that the effects of benzils $11 \mathrm{c}$ and 11d on cellular cycle correlated well with their antitubulin activity and also induced apoptosis at low concentrations in the tested cell lines.

Figure 4. Apoptotic effects of benzils 11c and 11d in H1299 cells. The results are expressed in the percentage of apoptotic cells induced by different concentrations of $11 \mathrm{c}$ and $\mathbf{1 1 d}$ (evaluation after $48 \mathrm{~h}$ of treatment).

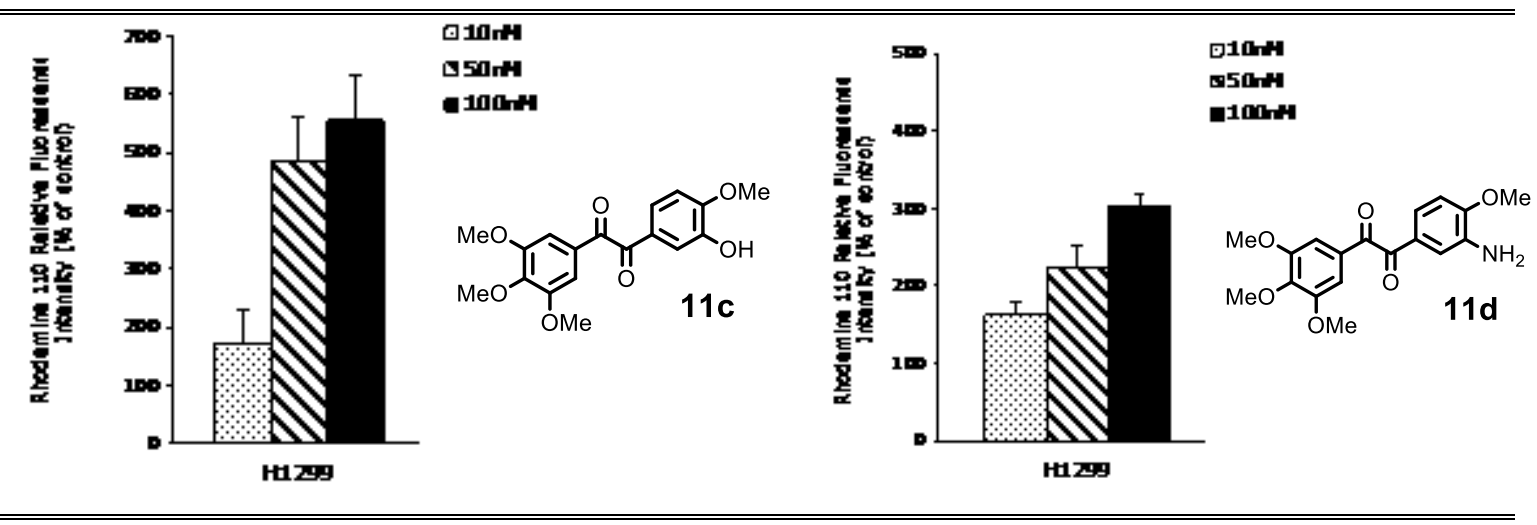

\subsubsection{Effect of 11d on human umbilical vein endothelial cell (HUVEC) organization.}

In order to expand this study, the effects of compound 11d on the proliferation of normal endothelial cells (HUVEC) were determined. After $72 \mathrm{~h}$ of incubation, 11d showed cytotoxic activity at a nanomolar level $\left(\mathrm{GI}_{50}=40 \mathrm{nM}\right)$ on the human umbilical 
vein endothelial cells. Additionally, the ability of 11d to disrupt a network of capillary-like tubular structures formed by endothelial cells on a matrigel matrix was evaluated (Figure 5).

Figure 5. Effects of benzil 11d on newly formed vessels.

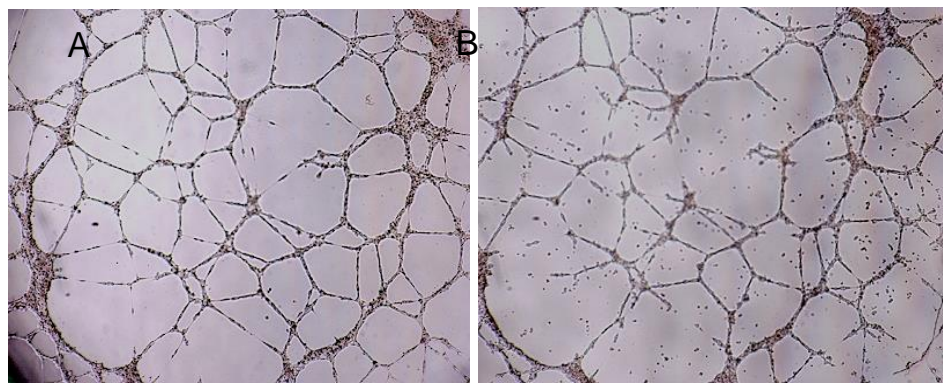

In vitro, vehicle or 11d was added to cords formed by endothelial cells on Matrigel, $24 \mathrm{~h}$ after HUVEC seeding; images were taken $3 \mathrm{~h}$ after addition of the compound. (A) Control; (B) 11d (100 nM).

Addition of $\mathbf{1 1 d}$ to formed cords at a concentration of $100 \mathrm{nM}$ and subsequent incubation disrupt rapidly the vascular network. It is interesting to note that this effect was visible after $3 \mathrm{~h}$ of treatment and at a dose of $100 \mathrm{nM}$ which was not cytotoxic for such incubation time (data not shown). Altogether, these results indicated that benzil 11d is identified as a promising lead in the development of new antivascular compounds. From a SAR purpose, the biological data collected in this study show that the replacement of the $(Z)$-olefin in CA-4 by two carbonyl groups is well tolerated and led highly potent derivatives. It is important to note that the two carbonyls present in compounds $\mathbf{1 1}$ are important for potent anticancer properties. Indeed, dehydrocombretastatin A-4 also named erianin 14 (Figure 6), which was prepared from the CA-4 reduction [50] was found to be less cytotoxic than its parent CA-4 [51] and slightly less potent as an inhibitor of tubulin polymerization ( $\mathrm{IC}_{50}=3.3 \mu \mathrm{M}$ for erianin). [52]

Figure 6. Selected CA-4 analogues having a two atoms linker, erianin 14, benzamide 15, and ketones 16 and 17.

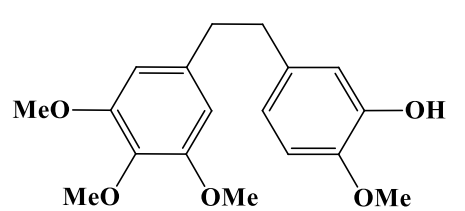

14 erianin

$\mathrm{GI}_{50} / \mathrm{GI}_{50} \mathrm{CA}-4=650^{a}$

ITP: $\mathrm{IC}_{50} / \mathrm{IC}_{50} \mathrm{CA}-4=1.7$

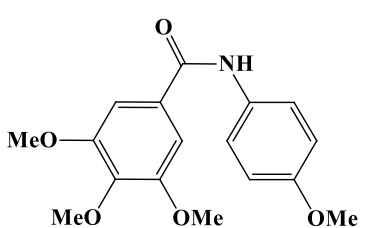

15

Not cytotoxic ITP: $\mathrm{IC}_{50} / \mathrm{IC}_{50} \mathrm{CA}-4=17$

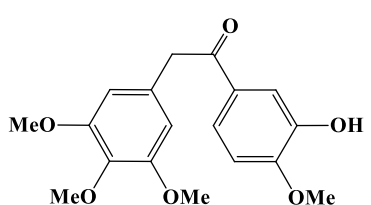

16

Not cytotoxic

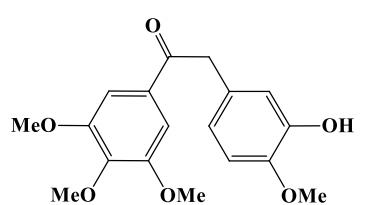

17

Not cytotoxic

${ }^{\bar{a} \mathrm{HCT} 29 \text { cells. }}$

Similarly, the replacement of one carbonyl in benzil of type $\mathbf{1 1}$ by a $\mathrm{NH}$ group resulted in significant decrease in cytotoxicity and antubulin properties as it was demonstrated with benzamide 15. [53] Finally, desoxybenzoin analogues 16 and 17 were inactive [51] showing again the crucial role for activity of the two adjacent carbonyls may be for hybridization considerations.

\subsection{C1-linkers}

We next focused our attention on the synthesis of CA-4 analogues having various C1-linkers with Csp ${ }^{2}$ and Csp ${ }^{3}$ at the A- and Bring junction. Concerning $\mathrm{Csp}^{2}$ hybridization, we first examined the synthesis and evaluation of di-substituted ethylenes 18-20, trisubstituted ethylenes 21, 22 and tetrasubstituted ethylenes 23. Then restricted derivatives having the double bond inserted into the B-ring were examined with dihydronaphtalenes 30, chromenes 32 and benzoxepins 33. Concerning Csp ${ }^{3}$ hybridization, we also studied the synthesis and the evaluation of erianin analogues $\mathbf{3 7}$ and diarylmethane compounds $\mathbf{3 8}$.

\subsubsection{C1-linker: diarylethylenes 18-20.}

\subsubsection{Synthesis of 1,1-diarylethylenes 18-20.}


We began the C1-linker program by the synthesis of 1,1-diarylethylene derivatives 18-20 having a C1-linker between the aromatic A and B-rings. It should be noted that compound 18a, a structural phenstatin analogue [38] which is also the third isomer of the natural CA-4, named isoCA-4, [54] has never been studied despite the impressive number of synthetic analogues. From a synthetic point of view, the access to 1,1-diarylethylene derivatives 18-20 was envisioned in our lab according to several routes including, the Pd-coupling of $\mathrm{N}$-tosylhydrazones [54-56] or vinylstannanes [57] with aryl halides or triflates, the addition of Grignard reagents to acetophenones followed by dehydration and Wittig olefination of phenstatin derivatives. [58] The synthesis of 1,1diarylethylenes 18a-f is described in Scheme 3.

Scheme 3. ${ }^{a}$ Synthesis of selected diarylethylenes 18a-f.

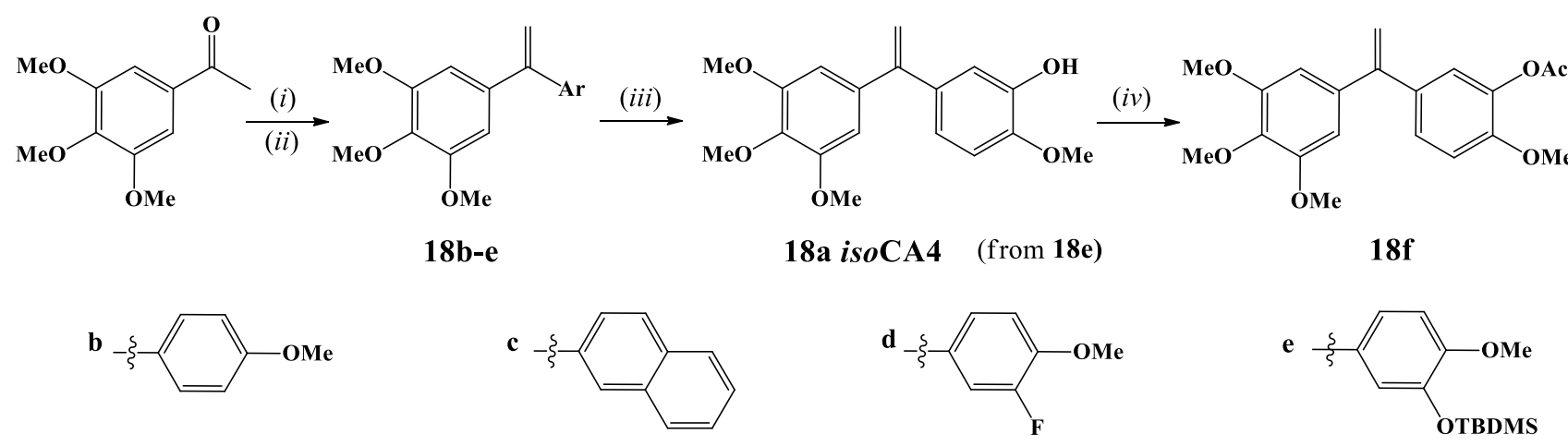

18d isoFCA4

${ }^{a}$ Reagents and conditions: (i) ArMgBr, THF, $-40{ }^{\circ} \mathrm{C}$ or ArLi, hexanes/toluene: 1/3. (ii) PTSA, (10 mol\%), $\mathrm{CH}_{2} \mathrm{Cl}_{2}$, rt. (iii) $\mathrm{K}_{2} \mathrm{CO}_{3}, \mathrm{MeOH}, \mathrm{rt} .($ iv) $\mathrm{Ac}_{2} \mathrm{O}, \mathrm{Pyr}, \mathrm{CH}_{2} \mathrm{Cl}_{2}$.

Diarylethylene derivatives 18b-e were prepared from 3,4,5-trimethoxyacetophenone through addition of arylGrignard or aryllithium reagents. [59] Crude tertiary alcohols were then treated with a catalytic amount of PTSA in $\mathrm{CH}_{2} \mathrm{Cl}_{2}$ and furnished $\mathbf{1 8 b}$ e in good yields. IsoCA-4 18a was obtained from alkaline desilylation of $\mathbf{1 8 e}$ in $\mathrm{MeOH}$ in a good $94 \%$ yield.

Scheme 4. ${ }^{a}$ Synthesis of selected nitrogen-containing diarylethylenes 19a-c.<smiles>C=C(c1cc(OC)c(OC)c(OC)c1)c1ccc(OC)c([N+](=O)[O-])c1</smiles><smiles>C=C(c1ccc(OC)c(N)c1)c1cc(OC)c(OC)c(OC)c1</smiles>

19b iso $\mathrm{NH}_{2} \mathrm{CA}-4$<smiles>C=C(c1ccc(OC)c(N)c1)c1cc(OC)c(OC)c(OC)c1</smiles>

19c iso $\mathrm{N}_{3} \mathrm{CA}-4$

${ }^{a}$ Reagents and conditions: (i) ArMgBr, THF, $-78{ }^{\circ} \mathrm{C}$ (ii) $\mathrm{PCC}, \mathrm{CH}_{2} \mathrm{Cl}_{2}, 20{ }^{\circ} \mathrm{C}$ (iii) $\mathrm{Ph}_{3} \mathrm{PCH}_{3} \mathrm{Br}$, LiHMDS, THF, $0{ }^{\circ} \mathrm{C}$ to $20{ }^{\circ} \mathrm{C}($ iv) $\mathrm{Zn}, \mathrm{AcOH}, 20$ ${ }^{\circ} \mathrm{C}(v) \mathrm{NaNO}_{2}, \mathrm{NaN}_{3}, \mathrm{HCl}_{\mathrm{aq}}$, acetone, $0{ }^{\circ} \mathrm{C}$.

Because in the CA-4 series it has been demonstrated that the C3'-OH group is amenable to modifications, [7, 59, 60] we have prepared other isoCA-4 analogues having C3'-nitrogen or C3'-carbon substituents. [61] Nitrogen-containing substrates 19a,b were prepared from the condensation of 4-methoxy-3-nitrobenzaldehyde with 3,4,5-trimethoxyphenylmagnesium bromide in THF. The resulting alcohol was oxidized with $\mathrm{PCC}$ in $\mathrm{CH}_{2} \mathrm{Cl}_{2}$ and a further Wittig reaction afforded 19a which underwent reduction of the nitro function, using $\mathrm{Zn}$ in $\mathrm{AcOH}$ to provide $\mathbf{1 9 b}$ (Scheme 4). We also examined the replacement of the $\mathrm{C}^{\prime}$ '- $\mathrm{NH}_{2}$ group with an azide group affording $i s o \mathrm{~N}_{3} \mathrm{CA}-419 \mathrm{c}$. 
A third series of isoCA-4 analogues 20a-j with C-linked substituents the C3'-position was studied. Such compounds were prepared from diarylethylene $\mathbf{1 8 g}$ [61] having an iodine atom on C3' (Scheme 5). Heck and Suzuki couplings afforded in good yields 3'-(E)-cinnamate 20a and diaryl derivative 20d, respectively. The preparation of acetylenic isoCA-4 analogues $\mathbf{2 0 e}$ and 20g,h was successfully achieved by Sonogashira-Linstrumelle couplings. For SAR considerations, the acetylenic triple bond of compound 20h was hydrated using a catalytic amount of PTSA in EtOH under microwave irradiation. [62, 63] Under this metalfree procedure, arylketone $\mathbf{2 0 i}$ was regioselectively obtained. When applying the same PTSA-protocole to orthomethoxydiarylalkyne $\mathbf{2 0 g}$, a 5-endo-dig-cyclization process occurred to give $[64,65] \mathbf{2 0 j}$ in a good yield of $86 \%$.

Scheme 5. 'Synthesis of selected C3' substitued diarylethylenes 20a-j from 18g.<smiles>C=C(c1cc(OC)c(OC)c(OC)c1)c1ccc(OC)c(C(=O)CCOCC)c1</smiles><smiles>C1CCCCC1</smiles><smiles>[R]C#Cc1cc(C(=C)c2cc(OC)c(OC)c(OC)c2)ccc1OC</smiles>

$$
\text { 20e } \mathrm{R}=\mathrm{SiMe}_{3}
$$$$
20 \mathrm{~g} \mathrm{R}=4-\mathrm{MeOPh}
$$$$
\text { 20h } \mathrm{R}=\mathrm{CH}_{2} \mathrm{OH}
$$$$
\text { (vii) }
$$<smiles>C#Cc1cc(C(=C)c2cc(OC)c(OC)c(OC)c2)ccc1OC</smiles>

$20 f$ from $20 \mathrm{e}$<smiles>C=C(c1cc(OC)c(OC)c(OC)c1)c1ccc2oc(-c3ccc(OC)cc3)cc2c1</smiles>

20j from 20g<smiles>C=C(c1ccc(OC)c(/C=C/CO)c1)c1cc(OC)c(OC)c(OC)c1</smiles>

20c

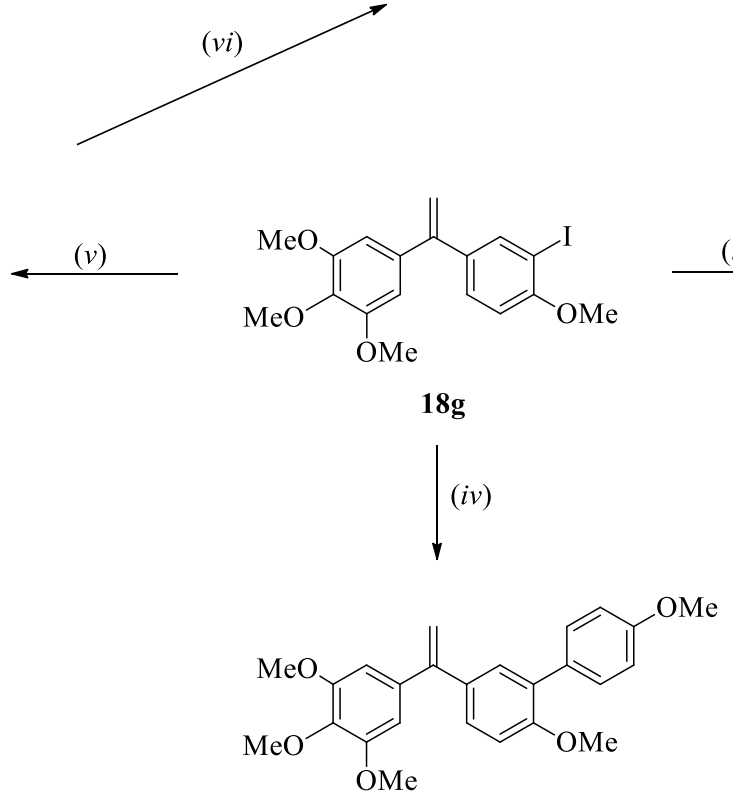

20d<smiles>C=C(c1ccc(OC)c(/C=C/C(C)=O)c1)c1cc(OC)c(OC)c(OC)c1</smiles>

$20 \mathbf{a}$

(ii)<smiles>C=C(c1ccc(OC)c(/C=C/C(=O)O)c1)c1cc(OC)c(OC)c(OC)c1</smiles>

${ }^{a}$ Reagents and conditions: (i) Methyl acrylate, $\mathrm{PdCl}_{2}\left(\mathrm{PPh}_{3}\right)_{2}, \mathrm{Et} 3 \mathrm{~N}$, DMF, $60{ }^{\circ} \mathrm{C}$; (ii) $\mathrm{NaOH}, \mathrm{MeOH}, \mathrm{rt}$; (iii) DIBAH, THF, -78 ${ }^{\circ} \mathrm{C}$; (iv) $4-$ $\mathrm{MeOPhB}(\mathrm{OH})_{2}, \mathrm{Pd}\left(\mathrm{PPh}_{3}\right)_{4}, \mathrm{NaHCO}_{3}, \mathrm{DME}_{-} \mathrm{H}_{2} \mathrm{O}$, reflux; (v) Alkyne, $\mathrm{PdCl}_{2}\left(\mathrm{PPh}_{3}\right)_{2}, \mathrm{CuI}, \mathrm{Et}_{3} \mathrm{~N}$, THF; (vi) PTSA, EtOH, microwave, $170{ }^{\circ} \mathrm{C} ;($ vii $)$ TBAF, THF, rt.

\subsubsection{Biological results.}

Table 2. Cytotoxicity of selected compounds $\mathbf{1 8 - 2 0}$ against HCT116 cancer cells

\begin{tabular}{|c|c|c|c|c|c|c|c|}
\hline Compounds & $\mathrm{GI}_{50} \mathrm{nM}^{\mathrm{a}}$ & Compounds & $\mathrm{GI}_{50} \mathrm{nM}^{\mathrm{a}}$ & Compounds & $\mathrm{GI}_{50} \mathrm{nM}^{\mathrm{a}}$ & Compounds & $\mathrm{GI}_{50} \mathrm{nM}^{\mathrm{a}}$ \\
\hline isoCA-4 (18a) & 2 & $19 a$ & 60 & 20d & 300 & $20 j$ & 4500 \\
\hline $18 b$ & 40 & isoNH $\mathrm{NH}_{2} \mathrm{CA}-4$ (19b) & 2 & $20 \mathrm{e}$ & 730 & CA-4 & 2 \\
\hline $18 c$ & 80 & iso $\mathrm{N}_{3} \mathrm{CA}-4$ (19c) & 72 & $20 f$ & 30 & & \\
\hline isoFCA-4 (18d) & 7 & $20 a$ & 80 & $20 \mathrm{~g}$ & 1500 & & \\
\hline $18 \mathrm{e}$ & 180 & $20 \mathrm{~b}$ & 80 & $20 h$ & 30 & & \\
\hline $18 f$ & 8 & $20 c$ & 45 & $20 \mathrm{i}$ & $\mathrm{NA}^{\mathrm{b}}$ & & \\
\hline
\end{tabular}

${ }^{a}$ A sample's concentration which produces a 50\% reduction cell growth. ${ }^{b}$ Not active.

2.4.1.2.1 Cytotoxicity. As mentioned in Table 2, several 1,1-diarylethylene derivatives retained potent growth inhibitory activity at a nanomolar level, and lowest $\mathrm{GI}_{50}$ values were obtained with isoCA-4, isoFCA-4, iso $\mathrm{NH}_{2} \mathrm{CA}-4$ and ester 18f. These values, and 
particularly the one of isoCA-4 $\left(\mathrm{GI}_{50}=2 \mathrm{nM}\right)$, are comparable to that of CA-4 showing that the replacement of the $(\mathrm{Z})-1,2-$ ethylene by a 1,1-ethylene bridge resulted in retention of cytotoxicity in these series of compounds. It is noteworthy that a fluorine atom, a $\mathrm{NH}_{2}$ substituent or an acetate function on the $\mathrm{C}_{3}$ '-position are well tolerated leading to potent compounds with $\mathrm{GI}_{50}$ values ranging from 2 to $8 \mathrm{nM}$. Moreover, we were pleased to observe that compounds 20h and 20c having on the C3'-position, a propyn-ol or a propen-ol chain respectively, displayed a high level of cytotoxicity $(30-45 \mathrm{nM})$. These preliminary cytotoxic results led us to explore the potential of the more active 1,1-diarylethylenes against other cancer cell lines.

As shown in Table 3, all 1,1-diarylethylenes exhibited similar potent cytotoxic effects against the tested cancer cell lines. It should be noted that in the 1,1-diarylethylene series, isoCA-4, iso $\mathrm{NH}_{2} \mathrm{CA}-4$ and isoFCA-4 displayed $\mathrm{GI}_{50}$ of 3 to $8 \mathrm{nM}$, which was similar to that obtained for CA-4. Again, 1,1-diarylethylenes 20c and 20h having alkenyl or alkynyl chains on C3' were cytotoxic against all cancer cells.

Table 3. Cytotoxicity of selected 1,1-diarylethylenes $\mathbf{1 8 - 2 0}$ in various cancer cells ${ }^{\mathrm{a}}$

\begin{tabular}{|c|c|c|c|c|c|c|c|c|}
\hline & \multicolumn{7}{|c|}{ 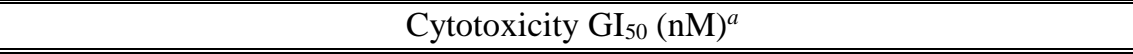 } & $\mathrm{ITP}^{\mathrm{b}}$ \\
\hline Compound & $\mathrm{K} 562^{b}$ & $\mathrm{U}^{2} 7^{b}$ & $\mathrm{~A} 549^{b}$ & MDA-MB435 ${ }^{b}$ & $\mathrm{MDA}^{-\mathrm{MB} 23^{b}}$ & $\mathrm{H} 1299^{b}$ & $\mathrm{HUVEC}^{b}$ & $\mathrm{IC}_{50}(\mu \mathrm{M})$ \\
\hline isoCA-4 & 5 & 8 & 8 & 4.5 & 4 & 5 & 1.5 & 2 \\
\hline $18 b$ & 18 & 28 & 20 & 25 & 10 & - & 38 & 2 \\
\hline isoFCA-4 & 4 & 7 & 7 & 8 & 3 & - & 5 & 4 \\
\hline iso $\mathrm{NH}_{2} \mathrm{CA}-4$ & 4 & 8 & 7 & 7 & 6 & 9 & 3 & 1.5 \\
\hline iso $\mathrm{N}_{3} \mathrm{CA}-4$ & 28 & - & - & - & 30 & 50 & - & 3 \\
\hline $20 \mathbf{a}$ & 80 & - & - & - & 500 & 70 & - & 2 \\
\hline $20 b$ & 80 & - & - & - & 500 & 70 & - & 3 \\
\hline $20 \mathrm{c}$ & 2 & - & - & - & 5 & 5 & - & 2 \\
\hline $20 f$ & 20 & - & - & - & 30 & 35 & - & 67 \\
\hline $20 \mathrm{~h}$ & 35 & - & - & - & 7 & 25 & - & 2 \\
\hline $\mathbf{C A}-4^{d}$ & 3.5 & 3 & 7 & 3 & 3.5 & 5 & 2.5 & 1 \\
\hline
\end{tabular}

${ }^{a} \mathrm{GI} 50$ is the concentration of compound needed to reduce cell growth by $50 \%$ following $72 \mathrm{~h}$ cell treatment with the tested drug (average of three experiments). ${ }^{b} \mathrm{~K} 562$, myelogenous leukaemia; U87, glioblastome; A549, carcinomic alveolar basal epithelial; MDA-MB435, breast cancer and MDA-MB231 hormone-independent breast cancer; H1299 non-small cell lung carcinoma, HUVEC human umbilical vein endothelial cell, ITP, Inhibition of Tubulin Polymerization; $\mathrm{IC}_{50}$ is the concentration of compound required to inhibit 50\% of the rate of microtubule assembly (average of three experiments). ${ }^{c}$ Not determined. ${ }^{d}$ The $\mathrm{GI}_{50}$ and $\mathrm{IC}_{50}$ values (cytotoxicity and ITP respectively) for CA-4 was determined in this study.

\subsection{Antitubulin activity.}

The effect on in vitro polymerization of tubulin of 1,1-diarylethylenes was next examined. On the exception of terminal alkyne 20f, all selected derivatives were excellent inhibitors of tubulin assembly with $\mathrm{IC}_{50}$ values ranging from 1.5 to $6 \mu \mathrm{M}$ (Table 3 ). As it was observed for benzil derivatives 11, we conclude that the antiproliferative activity of the selected 1,1-diarylethylenes derives from an interaction with the colchicine site of tubulin and an interference with microtubule assembly.

\subsection{Effects on cell cycle distribution and apoptosis.}

The effect of the more potent diarylethylenes, isoCA-4, iso $\mathrm{NH}_{2} \mathrm{CA}-4$ and isoFCA-4 on cell cycle distribution at a concentration of $10 \mathrm{nM}$ was evaluated on MDA-MDB231, K562 and HCT116 cancer cell lines. As depicted in Figure 7, these compounds caused a massive cell accumulation in the $\mathrm{G}_{2} / \mathrm{M}$ phase at a low concentration of $10 \mathrm{nM}$. Similarly, 1,1-diarylethylenes $\mathbf{2 0 c}$ and $20 \mathbf{h}$, having alken-ol and alkyn-ol substituents on the C3'-position arrest the cellular cycle in the $\mathrm{G}_{2} / \mathrm{M}$ phase at a low concentration on various cancer cell lines (data not shown). The effect of isoCA-4 on induction of apoptosis in HCT116, MDA-MDB 231 and K562 cells was next studied. The results presented in Figure 8 show a significant dose-dependent increase in proteolytic activity of caspases-3 and -7 in the cells treated for $24 \mathrm{~h}$ with isoCA-4. A spectacular 12- to 15-fold increase in apoptosis was evidenced in K562 
leukemia cells previously described as being resistant to apoptosis induction by a variety of agents including diphtheria toxin, camptothecin, cytarabine, etoposide, paclitaxel, staurosporine, and antifas antibodies. [66-71] Similar results were obtained with isoFCA-4 and iso $\mathrm{NH}_{2} \mathrm{CA}-4$ which induce apoptosis in the three tested cell lines. [58]

Figure 7. Effect of isoCA-4 (blue), iso $\mathrm{NH}_{2} \mathrm{CA}-4$ (pink) and isoFCA-4 (green) on cell cycle distribution in various cancer cell lines at $10 \mathrm{nM}$ (DMSO control in red).

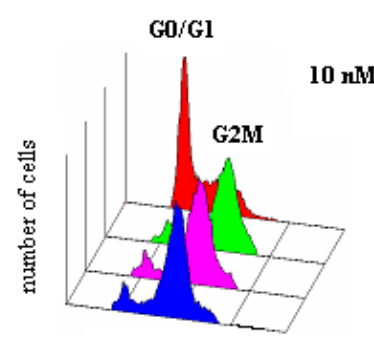

DNA content

MDA-MDB 231

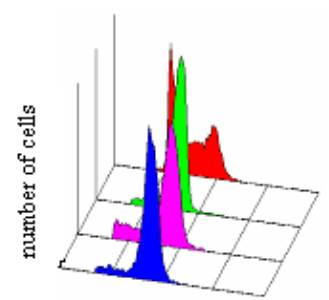

DNA content

K562

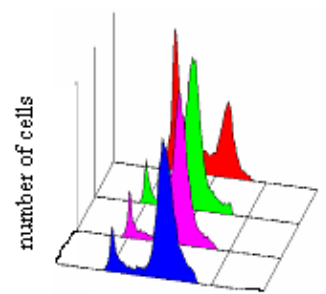

DNA content

HCT116

Figure 8. Apoptotic effect of $i s o$ CA-4 against HCT116, MDA-MDB231 and K562 cells. ${ }^{a}$

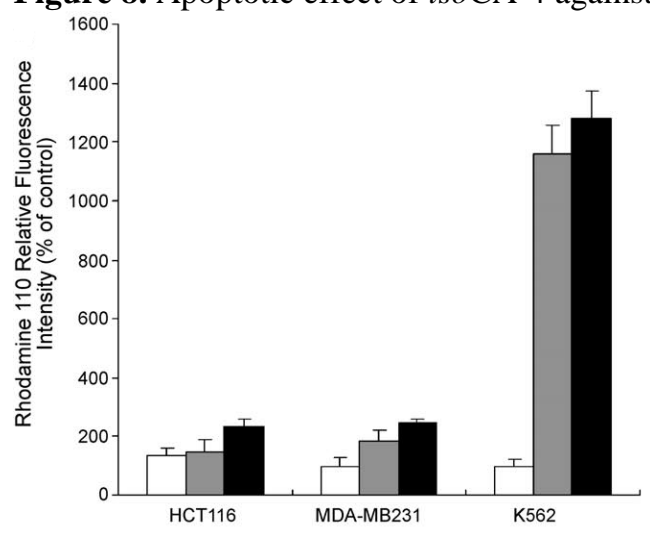

${ }^{a}$ The results are expressed in the percentage of apoptotic cells detected following $24 \mathrm{~h}$ treatment with isoCA-4 at different concentrations $1 \mathrm{nM}$ (white), $5 \mathrm{nM}$ (gray) and $10 \mathrm{nM}$ (black).

\subsection{Effect of isoFCA-4, isoCA-4 and iso $\mathrm{NH}_{2} \mathrm{CA}-4$ on HUVEC organization.}

The effects of the more active compounds isoFCA-4, isoCA-4 and iso $\mathrm{NH}_{2} \mathrm{CA}-4$ on the proliferation of normal endothelial cells were evaluated.

Figure 9. Effects of isoFCA-4, isoCA-4 and iso $\mathrm{NH}_{2} \mathrm{CA}-4$ on newly formed vessels.

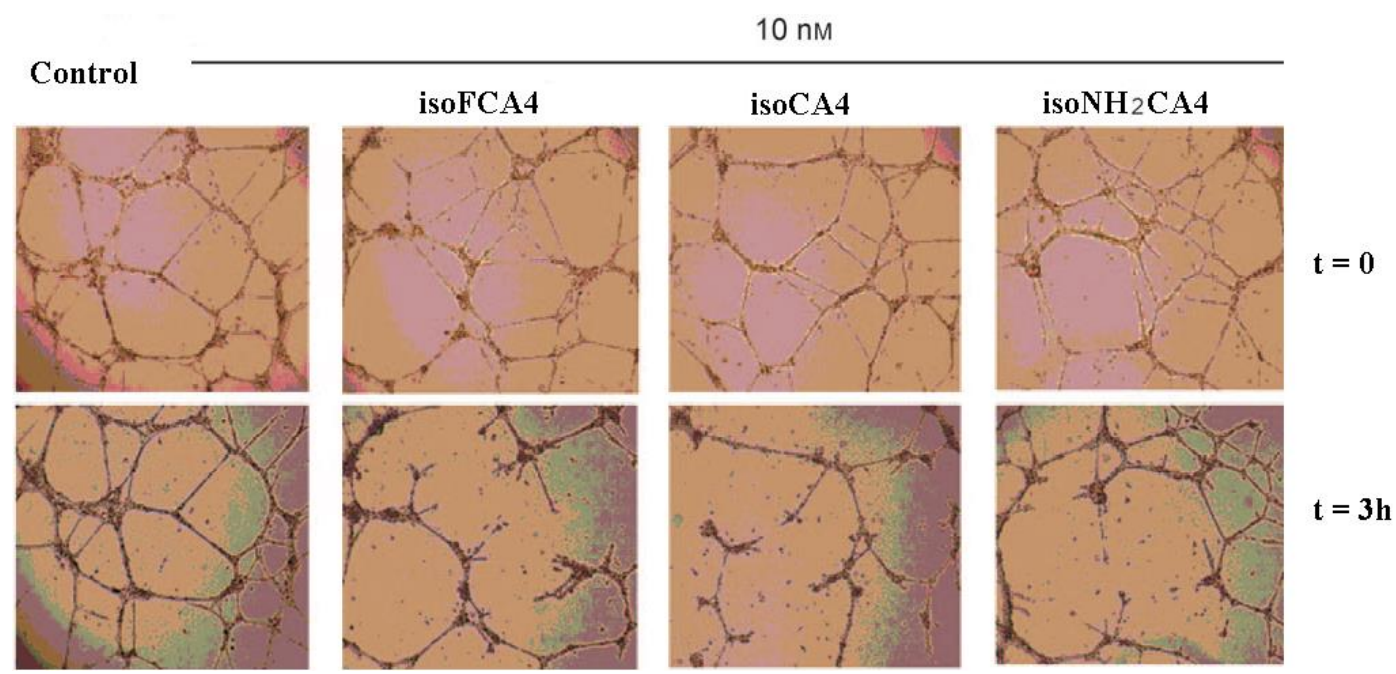


As shown in Figure 9, isoFCA-4, isoCA-4 and iso $\mathrm{NH}_{2} \mathrm{CA}-4$ disrupt the vessels-like structure and the integrity of the entire network at a concentration of $10 \mathrm{nM}$ after a short reaction time of $3 \mathrm{~h}$ which was shown to be not toxic for HUVEC. [58] This preliminary result suggests that isoCA-4 and some 1,1-diarylethylene analogues such as isoFCA-4 and isoNH $\mathrm{NAA}_{2}-4$ may be new leads for the development of antivascular agents.

\subsubsection{C1-linker: trisubstituted ethylenes 21 and 22.}

\subsubsection{Synthesis and evaluation of trisubstituted olefins 21. [72]}

The encouraging biological results obtained with diaryl-substituted olefins 18-20 have encouraged us to study a novel series of trisubstituted olefins 21. Such derivatives were prepared by palladium-catalyzed coupling of $N$-tosylhydrazones with aryliodides (Scheme 6).

Scheme 6. Synthesis and biological evaluation of trisubstituted olefins 21.<smiles>COCC(=[NH2+])c1cc(OC)c(OC)c(OC)c1</smiles><smiles>[R]c1cc(I)ccc1OC</smiles>

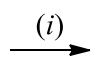

$\mathrm{OMe}$<smiles>[R]Oc1ccc(C(=COC)c2cc(OC)c(OC)c(OC)c2)cc1OC</smiles>

$\begin{aligned} \text { (ii) } \longrightarrow \text { 21c } \mathrm{R} & =\mathrm{OTBDMS} \\ \mathbf{2 1 d} \mathrm{R} & =\mathrm{OH} \quad(E / Z: 55 / 45)\end{aligned}$

21a $\mathrm{R}=\mathrm{NH}_{2}$ $(E / Z: 40 / 60)$ $21 \mathrm{~b} R=\mathrm{F}$ $(E / Z: 44 / 56)$

${ }^{a}$ Reagents and conditions: (i) $\mathrm{PdCl}_{2}(\mathrm{MeCN})_{2}(5 \mathrm{~mol} \%)$, dppp (10 mol\%), $\mathrm{Cs}_{2} \mathrm{CO}_{3}$, dioxane, $90{ }^{\circ} \mathrm{C} .($ ii $) \mathrm{K}_{2} \mathrm{CO}_{3}, \mathrm{MeOH}$, $\mathrm{rt}$.

The required $\mathrm{N}$-Tosylhydrazone was readily prepared from 3,4,5-trimethoxyacetophenone in 3 steps: bromination using $N$ methylpyrrolidin-2-one hydrotribromide (MPHT) complex develop in our group, [73-74] substitution of the bromine atom by $\mathrm{MeOH}$ in the presence of $\mathrm{Ag}_{2} \mathrm{CO}_{3} / \mathrm{BF}_{3}$. Et $2 \mathrm{O}$ [75] and finally hydrazone formation using $p$-toluenesulfonylhydrazide. Hydrazone was then coupled with various aryliodides under our previous reported conditions [76] using $\mathrm{PdCl}_{2}\left(\mathrm{MeCN}_{2} / \mathrm{dppp}\right.$ as the catalytic system and $\mathrm{Cs}_{2} \mathrm{CO}_{3}$ as the base. The OTBDMS protecting group of 21c was removed using $\mathrm{K}_{2} \mathrm{CO}_{3}$ in $\mathrm{MeOH}$ to yield phenol 21d. Enol ethers 21a,b and 21d were tested as a mixture of (E)- and (Z)-isomers against HCT116, K562 and H1299 cells.

Table 4. Cytotoxicity against HCT116, K562 and H1299 cells and ITP of 21a,b and 21d.

\begin{tabular}{ccccc}
\hline \hline & \multicolumn{3}{c}{ Cytotoxicity $\mathrm{GI}_{50}(\mathrm{nM})$} & $\mathrm{ITP}$ \\
Compound & HCT116 & K562 & H1299 & $\mathrm{IC}_{50}(\mu \mathrm{M})$ \\
21a & 80 & 40 & 43 & 3 \\
21b & 8 & 39 & 60 & 30 \\
21d & 24 & 32 & 25 & 2 \\
isoCA-4 $^{a}$ & 2 & 2.2 & 4 & 1.5 \\
\hline \hline
\end{tabular}

$\overline{{ }^{a} \text { The } \mathrm{GI}_{50} \text { and } \mathrm{IC}_{50} \text { values (cytotoxicity and ITP respectively) for isoCA-4 }}$ was determined in this study.

The results presented in Table 4 demonstrated that trisubstituted enol ethers 21 displayed excellent antiproliferative activity against the three tested cell lines. Interestingly, fluorine derivative 21b which displayed the best cytotoxicity level against HCT116 cell line with a $\mathrm{GI}_{50}$ value of $8 \mathrm{nM}$ did not inhibited efficiently the tubulin polymerization $\left(\mathrm{IC}_{50}=30 \mu \mathrm{M}\right)$. On the contrary, enolether derivatives 21a and 21d which were found to be slightly less cytotoxic against HCT116 cells were very effective in their ability to inhibit tubulin assembly with $\mathrm{IC}_{50}$ values of 2 and $3 \mu \mathrm{M}$, respectively, comparable to that of isoCA-4. As it was previously reported for the most of antimitotic agents, these tubulin polymerization inhibitors $\mathbf{2 1 a}$ and 21d arrested the majority of $\mathrm{K} 562$ cells in the $\mathrm{G}_{2} / \mathrm{M}$ phase (data not shown) at a concentration of $50 \mathrm{nM}$. [72] The biological results obtained with trisubstituted olefins 21 prompted us to synthesized hybrid olefin 22 having in its structure the CA-4 and the isoCA-4 moities to combine within a single substance the anticancer effects of both isomers (Scheme 7). 


\subsubsection{Synthesis and evaluation of hybrid molecule 22}

Scheme 7. ${ }^{a}$ Synthesis of targeted olefin 22.

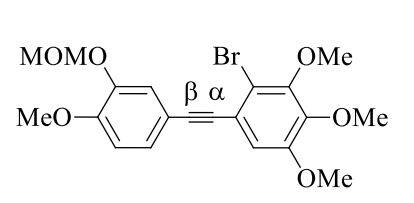

25
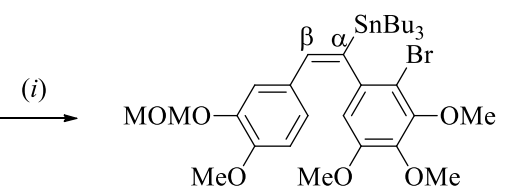

26

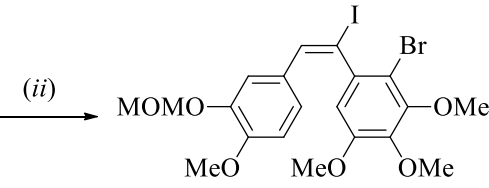

27

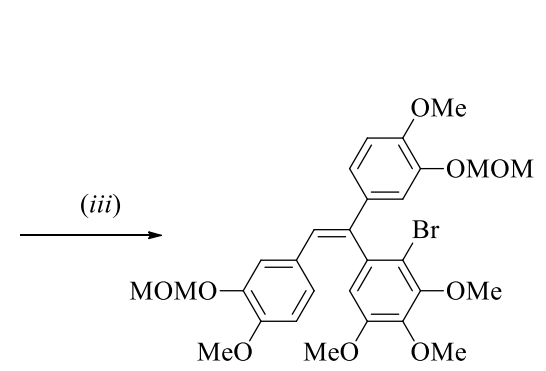

28

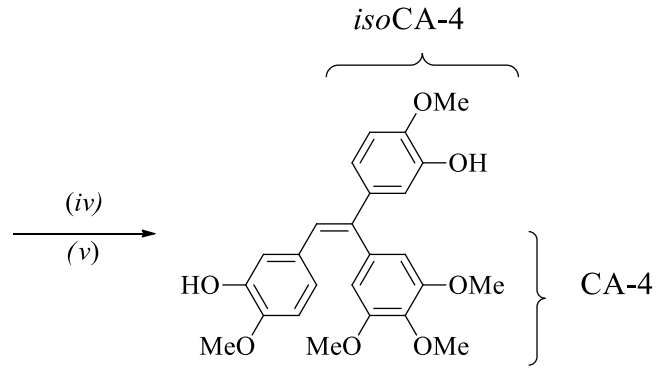

22

${ }^{a}$ Reagents and conditions: (i) $\mathrm{PdCl}_{2}\left(\mathrm{PPh}_{3}\right)_{2}$ (2 mol\%), $\mathrm{Bu} 3 \mathrm{SnH},\left(1.2\right.$ equiv), THF. (ii) $\mathrm{I}_{2}$ (1 equiv), $\mathrm{CH}_{2} \mathrm{Cl}_{2}, 20{ }^{\circ} \mathrm{C}$. (iii) $\mathrm{ArZnCl}(2.2$ equiv), $\mathrm{PdCl}_{2}\left(\mathrm{PPh}_{3}\right)_{2}(5 \mathrm{~mol} \%)$, THF. (iv) $n$-BuLi (4.5 equiv), THF, $-78{ }^{\circ} \mathrm{C}$. (v) $\mathrm{HCl} 1 \mathrm{M}, 20{ }^{\circ} \mathrm{C}$.

Triarylolefin 22 was prepared in five steps from diarylalkyne 25. [77] We have benefited from the presence of an ortho bromine atom on the trimethoxyphenyl ring of $\mathbf{2 5}$ to achieve a regioselective hydrostannation of the triple bond. [78-82] Under this orthodirecting effect (ODE) [79, 83], the reaction afforded exclusively $\alpha$-vinyl stannane $\mathbf{2 6}$ in a good $92 \%$ yield. A further iodolysis of 26 led to vinyl iodide 27 which underwent a Negishi coupling to furnish triarylolefin 28. [84] Finally, removal of the ortho bromo directing-group by halogen-metal exchange and subsequent hydrolysis, followed by MOM cleavage afforded triarylolefin $\mathbf{2 2}$ as a pure isomer. Unfortunately, olefin 22 was poorly cytotoxic against HCT116 cells with a $\mathrm{GI}_{50}$ values of $5 \mu \mathrm{M}$ and did not inhibited the polymerization of tubulin significantly. We suppose that triarylolefin $\mathbf{2 2}$ is probably too bulky to bind to the tubulin on the colchicine binding-site to explain these disappointing results.

\subsubsection{C1-linker: tetrasubstituted ethylenes 29.}

\subsubsection{Synthesis and evaluation of tetrasubstituted olefins 29}

We envisioned synthesizing a series of tetrasubstituted olefins 29 having on C2, different uncongested substituents enabling a binding on $\beta$-tubulin. Olefins 29a-m were selected to achieve this goal and their synthesis is described in Scheme 8 .

Scheme 8. ${ }^{a}$ Synthesis of tetrasubstituted olefins 29.<smiles>COc1cc(C(=[NH2+])C(C)C)cc(OC)c1OC</smiles><smiles>[TeH]</smiles><smiles>[X]c1cc(C(=C(C)C)c2cc(OC)c(OC)c(OC)c2)ccc1OC</smiles>
29a-d<smiles></smiles>

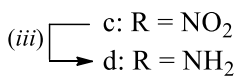<smiles>COc1cc(C(=[NH2+])C2CCC2)cc(OC)c1OC</smiles>
(i)<smiles>[X]c1cc(C(=C2CCC2)c2cc(OC)c(OC)c(OC)c2)ccc1OC</smiles>

29e-g

e: $\mathrm{R}=\mathrm{H}$

f: $\mathrm{R}=\mathrm{OMOM}$ $\mathrm{g}: \mathrm{R}=\mathrm{OH}$<smiles>COc1cc(C(=[NH2+])C2CCCC2)cc(OC)c1OC</smiles><smiles>COc1cc(C(=N)C2CCCCC2)cc(OC)c1OC</smiles><smiles>[Te]=[Te]</smiles><smiles>[X]c1cc(C(=C2CCCC2)c2cc(OC)c(OC)c(OC)c2)ccc1OC</smiles>

29h-l

h: $\mathrm{R}=\mathrm{H}$

$$
\begin{aligned}
(\text { ii) } \square \\
\mathrm{i}: \mathrm{R}=\mathrm{OMOM} \\
\mathrm{j}: \mathrm{R}=\mathrm{OH} \\
\text { (iii) } \square \text { k: } \mathrm{R}=\mathrm{NO}_{2} \\
\longrightarrow \mathrm{1}: \mathrm{R}=\mathrm{NH}_{2}
\end{aligned}
$$<smiles>COc1ccc(C(=C2CCC(C(=O)O)CC2)c2cc(OC)c(OC)c(OC)c2)cc1</smiles>

29m

${ }^{a}$ Reagents and conditions: (i) ArI (0.8 equiv), $\mathrm{PdCl}_{2}(\mathrm{MeCN})_{2}(5 \mathrm{~mol} \%)$, dppp (10 mol\%), $\mathrm{Cs}_{2} \mathrm{CO}_{3}$ (3 equiv), dioxane, $90{ }^{\circ} \mathrm{C} .($ ii $)$ PTSA, EtOH. (iii) $\mathrm{Fe}, \mathrm{HCl}, \mathrm{EtOH}, 100{ }^{\circ} \mathrm{C}$. 
Although the double bond in compounds $\mathbf{2 9}$ could be generated by a Wittig reaction, a more convergent approach was recently developed in our group. [76] We found that hindered polyoxygenated $N$-tosylhydrazones coupled with a variety of aryl iodides using $\mathrm{PdCl}_{2}(\mathrm{MeCN})_{2}$ as a catalyst, dppp as a ligand and of $\mathrm{Cs}_{2} \mathrm{CO}_{3}$ as a base in dioxane at $90{ }^{\circ} \mathrm{C}$. Under these optimized conditions, targeted tetrasubstituted olefins 29 were obtained in good yields (62-82\%). Preliminary antiproliferative results reveal that olefins 29 displayed a poor level of cytotoxicity. The most active molecules in this series were $\mathbf{2 9 b}$ and $29 \mathbf{g}$ with GI 50 values of 300 and $250 \mathrm{nM}$, respectively. These compounds were not effective to inhibit tubulin assembly with $\mathrm{IC}_{50}$ values superior to 10 $\mu \mathrm{M}$.

\subsubsection{C1-linker: conformationally restricted iso CA-4 analogues.}

2.4.4.1 Synthesis and biological evaluation of dihydronaphtalene 30 and naphthalene 31 derivatives. To increase binding affinity and then activity, conformational restriction by a cycle has been successfully envisioned by different groups with significative bioactive molecules 32 [85], 33 [86] and 34 [87] represented in Figure 10.

Figure 10. Cytotoxicity of restricted CA-4 analogues 32-34.<smiles>COc1cc(O)c2c(-c3ccc(OC)c(O)c3)cc(=O)oc2c1</smiles>

32

$\mathrm{GI}_{50}=83 \mathrm{nM}^{a}$<smiles>COc1cc(OC)c2c(-c3ccc4c(ccn4C)c3)cc(=O)oc2c1</smiles>

33<smiles>COc1cc(-c2cccc3c(O)c(OC)ccc23)cc(OC)c1OC</smiles>

34

$\mathrm{GI}_{50} / \mathrm{GI}_{50} \mathrm{CA}-4=0.014^{c}$

ITP: $\mathrm{IC}_{50} / \mathrm{IC}_{50} \mathrm{CA}-4=1.4$

${ }^{\mathrm{a}} \mathrm{CEM}$ leukemia cells. ${ }^{b} \mathrm{HBL} 100$ human epithelial mammary cells. ${ }^{c} \mathrm{NCI}-\mathrm{H} 460$ human non-small lung cancer cells.

Scheme 9. ${ }^{a}$ Synthesis of dihydronaphtalenes 30 and naphtalenes 31. [88]

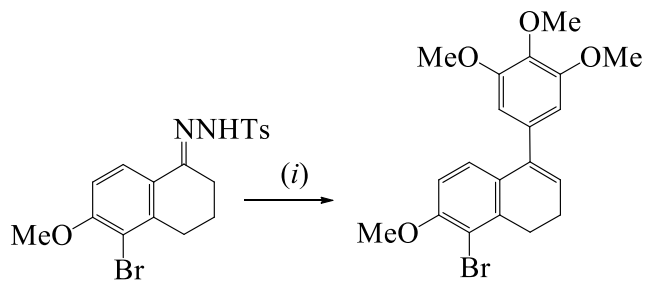

(ii) for $\mathbf{3 0 b}$

(iii) for 30c

(iv) for 30d<smiles>[R]c1ccc2c(c1)CCC=C2c1cc(OC)c(OC)c(OC)c1</smiles>

30 b-d

$30 \mathbf{a}$

(vii)

b $\mathrm{R}^{1}=\mathrm{H}$

c $\mathrm{R}^{1}=\mathrm{NH}_{2}$

d $\mathrm{R}^{1}=\mathrm{OH}$

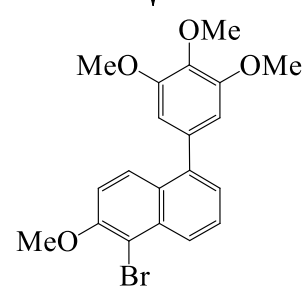

$31 \mathrm{a}$

\section{(ii) for 31b \\ (iii) for $31 \mathrm{c}$ \\ (iv) for 31d}

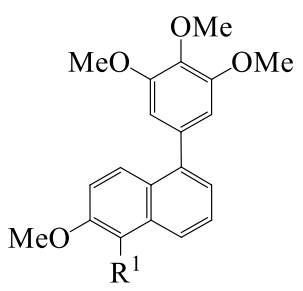

31b-d

aReagents and conditions: (i) 3,4,5-trimethoxyphenyl iodide (1.1 equiv), $\mathrm{Pd}_{2} \mathrm{dba}_{3}$ (10 mol\%), $\mathrm{XPhos}(40 \mathrm{~mol} \%)$, $\mathrm{LiO} t \mathrm{Bu}$ (2.2 equiv), dioxane $90{ }^{\circ} \mathrm{C}$ in a sealed tube. (ii) $\mathrm{Pd}(\mathrm{OAc})_{2}(5 \mathrm{~mol} \%)$, $\mathrm{PPh}_{3}(20 \mathrm{~mol} \%), \mathrm{K}_{2} \mathrm{CO}_{3}$ (2 equiv), $\mathrm{BuOH}, 100{ }^{\circ} \mathrm{C}$. (iii) $\mathrm{NaN}_{3}$ (2 equiv), CuI (10 mol\%), DMEDA (15 mol\%), sodium ascorbate (5 mol\%), DMSO/ $\mathrm{H}_{2} \mathrm{O}: 5 / 1,60{ }^{\circ} \mathrm{C}$. (iv) $\mathrm{KOH}$ (5 equiv), $\mathrm{Pd}_{2} \mathrm{dba}_{3}(10$ mol\%), $t$ BuXPhos $(20 \mathrm{~mol} \%)$, dioxane $/ \mathrm{H}_{2} \mathrm{O}: 1 / 1,90{ }^{\circ} \mathrm{C}$ in a sealed tube.

These considerations led us to prepare a series of new restricted isoCA-4 analogues by inserting an additional ring between the 1,1-ethylene double bond and the B-ring. Thus, dihydronaphtalene $\mathbf{3 0}$ and naphthalene derivatives $\mathbf{3 1}$ were designed and their synthesis is reported in Scheme 9. As previously reported, the pivotal dihydronaphtalene 30a was prepared by coupling its 
corresponding $\mathrm{N}$-tosylhydrazone with 3,4,5-trimethoxyiodobenzene under Pd-catalysis. Compound 30c, having a $\mathrm{NH}_{2}$ substituent was prepared from 30a in a 60\% yield, by using sodium azide as the amine source in the presence of CuI in EtOH. [89] Finally, phenol derivative 30d, having the greatest resemblance to isoCA-4 was prepared in a $63 \%$ yield using $\mathrm{KOH}$ as nucleophile under Pd-catalysis. [90] After an extensive research, a DDQ-oxidation of dihydronaphtalene 30a in $\mathrm{CH}_{2} \mathrm{Cl}_{2}$ at room temperature furnished naphtalene 31a in an acceptable yield of 45\%. As for 30a, structural modifications on the C-Br bond of 31a led to the desired naphthalene derivatives 31b-d.

All dihydronaphtalene $\mathbf{3 0}$ and naphthalene derivatives $\mathbf{3 1}$ were evaluated for their cytotoxicity toward HCT116 cells and best molecules were tested against H1299, MDA-MB231 and K562 cancer cell lines (Table 5).

Table 5. Cytotoxicity of selected compounds against different human cancer cell lines and ITP.

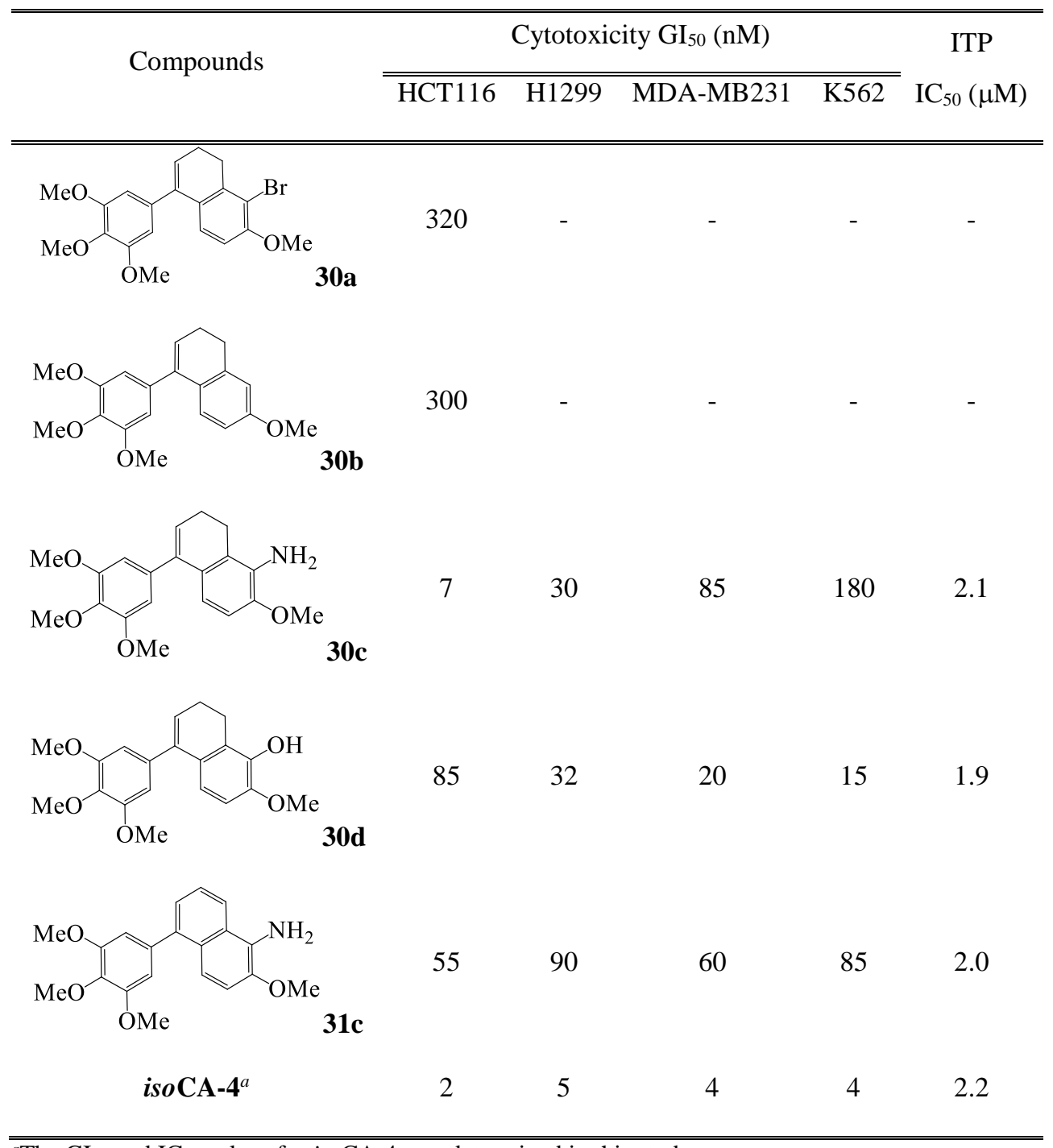

$\overline{\bar{a}}{ }^{\text {The }} \mathrm{GI}_{50}$ and $\mathrm{IC}_{50}$ values for $i s o \mathrm{CA}-4$ was determined in this study.

Naphtalene compounds were not cytotoxic against HCT116 (data not shown) except naphtylamine 31c which was found to be a potent inhibitor of tubulin assembly $\left(\mathrm{IC}_{50}=2 \mu \mathrm{M}\right)$. Nevertheless, 31c had $\mathrm{GI}_{50}$ values ranging from 55 to $90 \mathrm{nM}$ which are approximately 20 times less active than its non-restricted iso $\mathrm{NH}_{2} \mathrm{CA}-4$ analogue. Dihydronaphtalene derivatives $\mathbf{3 0}$ were found to be more cytotoxic than their naphthalene congeners 31. As observed in the isoCA-4 series, $\mathrm{NH}_{2}$ and $\mathrm{OH}$ substitutions led to cytotoxic molecules as observed for 30c and 30d. These two drugs which retained a high level a cytotoxicity against HCT116 cells were also strongly cytotoxic against H1299, MDA-MB231 and K562 cancer cell lines with GI 50 values ranging from 7 to $180 \mathrm{nM}$. Compounds 30c and 30d showed a tubulin polymerization $\mathrm{IC}_{50}$ similar to that of isoCA-4 (2.1 and 1.9 vs $\left.2.0 \mu \mathrm{M}\right)$. Next, to confirm that the mechanism of action of 30d was antimitotic, we evaluated its effect on cell cycle. As shown in Figure 11, compound 30d induced a prevalent block of cells in the $\mathrm{G}_{2} / \mathrm{M}$ phase of the cell cycle at a concentration of $10^{-8} \mathrm{M}$. 
Figure 11. Evaluation of $\mathrm{G}_{2} / \mathrm{M}$ arrest in MDA-MB231, K562, HCT116 and H1299 cells exposed to 30d.
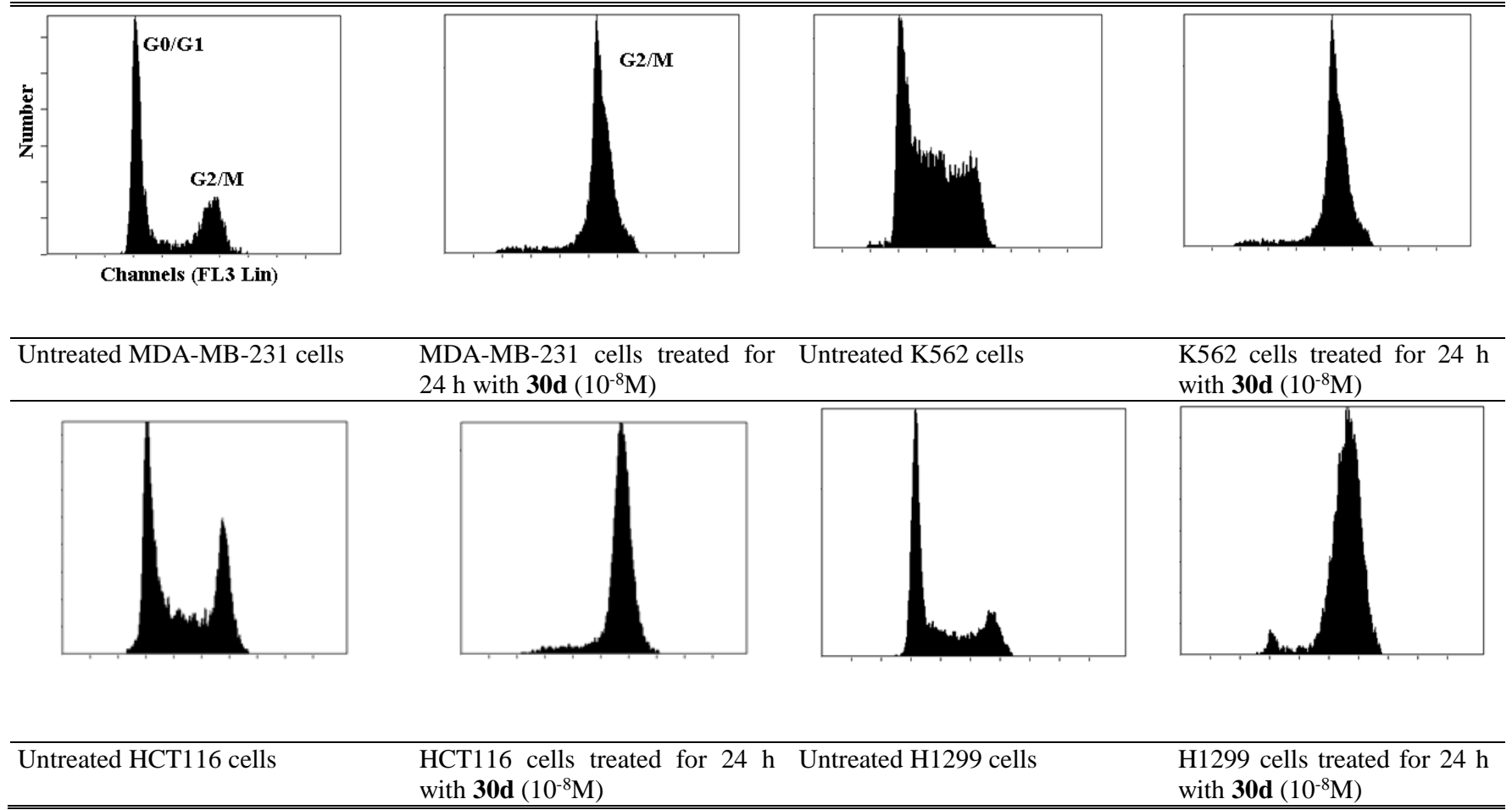

Recently, Pinney reported the synthesis of benzosuberene derivatives [87, 91] as highly cytotoxic agents and showed that the double bond in isoCA-4 could be included in a 7-membered ring to maintain potent activity. Having achieving our goal with dihydronaphtalenes and naphtalene derivatives, we next envisioned to prepare and evaluate a novel series of dihydrobenzoxepin derivatives 32 having a 7-membered heterocyclic-ring.

Scheme 10. ${ }^{a}$ Synthesis of benzoxepins 32a-d.

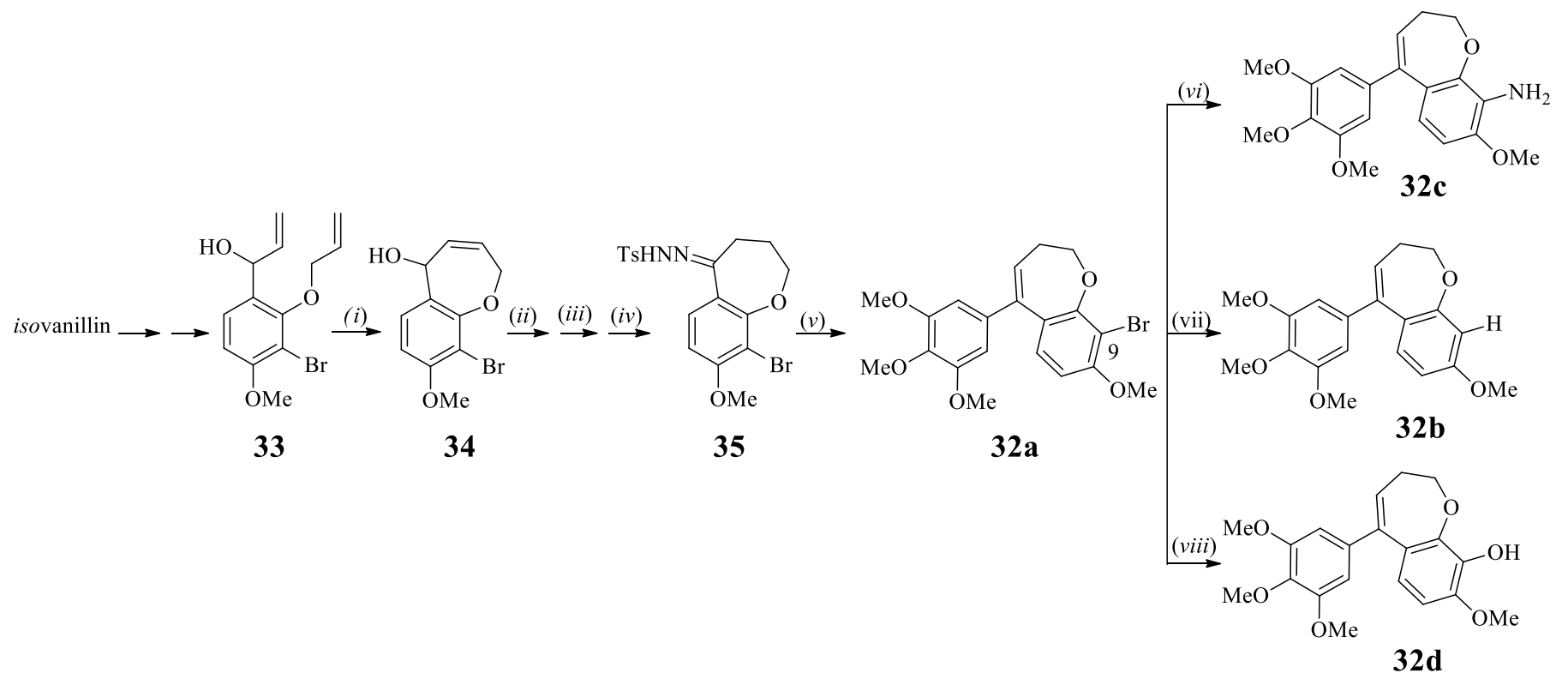

${ }^{a}$ Reagents and conditions: (i) Grubbs II catalyst, $\mathrm{CH}_{2} \mathrm{Cl}_{2}$, rt. (ii) $\mathrm{H}_{2}$, $\mathrm{Pd} / \mathrm{C}$, EtOAc. (iii) $\mathrm{PCC}, \mathrm{CH}_{2} \mathrm{Cl}_{2}$. (iv) N-tosylhydrazide, EtOH, reflux.3,4,5trimethoxyphenyl iodide 1.1 equiv, $\mathrm{Pd}_{2} \mathrm{dba}_{3}(10 \mathrm{~mol} \%)$, XPhos (40 mol\%), $\mathrm{LiO} t \mathrm{Bu}\left(2.2\right.$ equiv), dioxane $90{ }^{\circ} \mathrm{C}$, sealed tube. (iii) $\mathrm{Pd}(\mathrm{OAc})_{2}(5$ mol\%), $\mathrm{PPh}_{3}(20 \mathrm{~mol} \%), \mathrm{K}_{2} \mathrm{CO}_{3}$ (2 equiv), $\mathrm{BuOH}, 100{ }^{\circ} \mathrm{C}$. (iv) $\mathrm{NaN}_{3}$ (2 equiv), CuI (10 mol\%), DMEDA (15 mol\%), sodium ascorbate (5 mol\%), DMSO/ $\mathrm{H}_{2} \mathrm{O}: 5 / 1,60{ }^{\circ} \mathrm{C}$. (v) $\mathrm{KOH}$ (5 equiv), $\mathrm{Pd}_{2} \mathrm{dba}_{3}(10 \mathrm{~mol} \%), t \mathrm{BuXPhos}(20 \mathrm{~mol} \%)$, dioxane/ $\mathrm{H}_{2} \mathrm{O}: 1 / 1,90{ }^{\circ} \mathrm{C}$, sealed tube.

2.4.4.2 Synthesis and biological evaluation of benzoxepins 32.[92] The target molecules 32a-d were prepared from isovanillin (Scheme 10). Chemical amenagements of isovanillin afforded rapidly diene $\mathbf{3 3}$ which underwent ring-closing olefin metathesis 
using Grubbs II catalyst. The resulting dihydrobenzoxepin-5-ol 34 was subjected to double bond reduction, PCC oxidation and $N$ tosylhydrazone formation to give $\mathbf{3 5}$ in good yields. A further palladium-catalyzed coupling reaction with 3,4,5trimethoxyiodobenzene furnished the 9-bromo-8-methoxybenzoxepin 32a which was transformed into functionalized benzoxepins 32b-d as its was previously described for dihydronaphtalene 30a.

Benzoxepin derivatives 32a-d were evaluated against HCT116, H1299, K562 and MDA-MB-231 cells. The GI 50 values are shown in Table 6. Benzoxepin 32d, having a $\mathrm{OH}$ substituent on $\mathrm{C} 9$ was the most active compound in all cancer cells with $\mathrm{GI}_{50}$ values of 1.5-8 nM, comparable to that of $i s o \mathrm{CA}-4$. Derivative 32c having on the $\mathrm{C} 9$ portion a $\mathrm{NH}_{2}$ function, showed a lower but interesting level of cytotoxicity with $\mathrm{GI}_{50}$ values ranging from 8 to $40 \mathrm{nM}$. On the exception of 9-bromobenzoxepin 32a, compounds 32b-d strongly inhibited tubulin polymerization with similar $\mathrm{IC}_{50}$ values of 3.6-3.9 $\mu \mathrm{M}$ which were about two times greater than that of isoCA-4. Next, flow cytometry analysis indicated that the more potent benzoxepin $\mathbf{3 2} \mathbf{b}$, at a low concentration of $5 \mathrm{nM}$, arrested the cell cycle in the $\mathrm{G}_{2} / \mathrm{M}$ phase in H1299, K562, HCT116 and MDA-MB-231 cells [92] as it was previously observed with other antitubulin drugs. Furthermore, 32b was characterized as a strongly apoptotic agents at a low concentration of $5 \mathrm{nM}$ with a marked effect in H1299 cells (data not shown).

Table 6. Cytotoxicity of benzoxepins 32a-d against four cancer cell lines and IPT.

\begin{tabular}{|c|c|c|c|c|c|c|}
\hline & \multirow{2}{*}{ Compounds } & \multicolumn{4}{|c|}{ "Cytotoxicity $\mathrm{GI}_{50}(\mathrm{nM})$} & \multirow{2}{*}{$\begin{array}{c}\text { IPT } \\
\mathrm{IC}_{50}(\mu \mathrm{M}) \\
\end{array}$} \\
\hline & & HCT116 & $\mathrm{H} 1299$ & K562 & MDA-MB231 & \\
\hline $32 \mathbf{a}$ & & 170 & $\mathrm{ND}^{a}$ & $a$ & $a$ & $\mathrm{NA}^{b}$ \\
\hline $32 b$ & & 85 & 180 & 100 & 250 & 3.9 \\
\hline $32 c$ & & 22 & 30 & 40 & 8 & 3.6 \\
\hline \multirow[t]{2}{*}{ 32d } & & 1.5 & 4.5 & 8 & 3 & 3.8 \\
\hline & isoC & 2 & 5 & 5 & 4 & 2.2 \\
\hline
\end{tabular}

${ }^{a}$ ND Not determined. ${ }^{b} \mathrm{NA}$ Not active

Having succeeded in the syntheses of bioactive 1,1-diarylethylene derivatives, with isoCA-4 as lead compound, and in the preparation of restricted isoCA-4 derivatives, we next envisioned to reduce the ethylene double bond for SAR considerations.

\subsubsection{C1-linker: diarylethane 36 and diarylmethane 37 derivatives.}

2.4.5.1 Synthesis of isoerianin analogues 36. [93] On the basis of the previous bioisosteric considerations with diarylethylene compounds, we next hypothesized that compounds of type $\mathbf{3 6}$ having a 1,1-diarylethane scaffold could be as active as their 1,2diarylethylene isomers (Scheme 11). 
Scheme 11. Bioisosteric equivalence between natural erianin and isoerianin 36a.<smiles>CCCCCCCCCCc1ccc(OC)c(OC)c1</smiles>

erianin

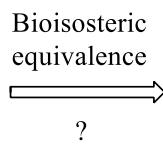<smiles>COc1cc([C@H]2c3cc4c(cc3[C@@H](O)[C@@H]3COC(=O)[C@H]23)OCO4)cc(OC)c1OC</smiles>

podophyllotoxin

In particular, it would be of interest to compare the biological properties of compound 36a, isoerianin, with its natural isomer and anticancer agent erianin. [94] Moreover, compounds of type 36 could be regarded as acyclic and simplified analogues of the antimitotic and antiproliferative podophyllotoxin. [95, 96] Isoerianin derivatives were prepared in a single step by reduction of 1,1-diarylethylene derivatives 28-30. The water-soluble phosphate $\mathbf{3 6 b}$ was obtained from isoCA-4 by phenol dibenzylphosphorylation followed by concomitant $\mathrm{H}_{2} / \mathrm{Pd}$-hydrogenolysis and double-bond reduction.

\subsubsection{Biological activities of isoerianin derivatives 36a-d.}

2.4.5.1.1 Cytotoxicity and inhibition of tubulin polymerization. The cytotoxicities against five human cancer and HUVEC cell lines of selected isoerianin compounds are presented in Table 7. It is of interest to note that isoerianin exhibited similar or greater cytotoxic activity than erianin with $\mathrm{GI}_{50}$ values ranging from 25 to $45 \mathrm{nM}$. Both enantiomers of isoerianin were separated by chiral HPLC and were found to display a similar level of cytotoxicity with GI $_{50}$ values of 26-29 nM against the HCT116 cancer cells (data not shown). Changing the C3'-OH by a phosphate group, as for water-soluble derivative 36b, decreased cytotoxicity by 2 fold as compared to isoerianin. Interestingly, indole 36c and $\mathrm{C}^{\prime}$ '- $\mathrm{NH}_{2}$-derivative $\mathbf{3 6} \mathbf{d}$ are the most cytotoxic agents in the 1,2diarylethane series 36. Examination of antitubulin properties of isoerianin reveal that this compound displayed a potent activity $\left(\mathrm{IC}_{50}=3 \mu \mathrm{M}\right)$ comparable to that of erianin $(1.5 \mu \mathrm{M})$.

Table 7. Cytotoxic activity and inhibition of tubulin polymerization of selected isoerianin derivatives 37.

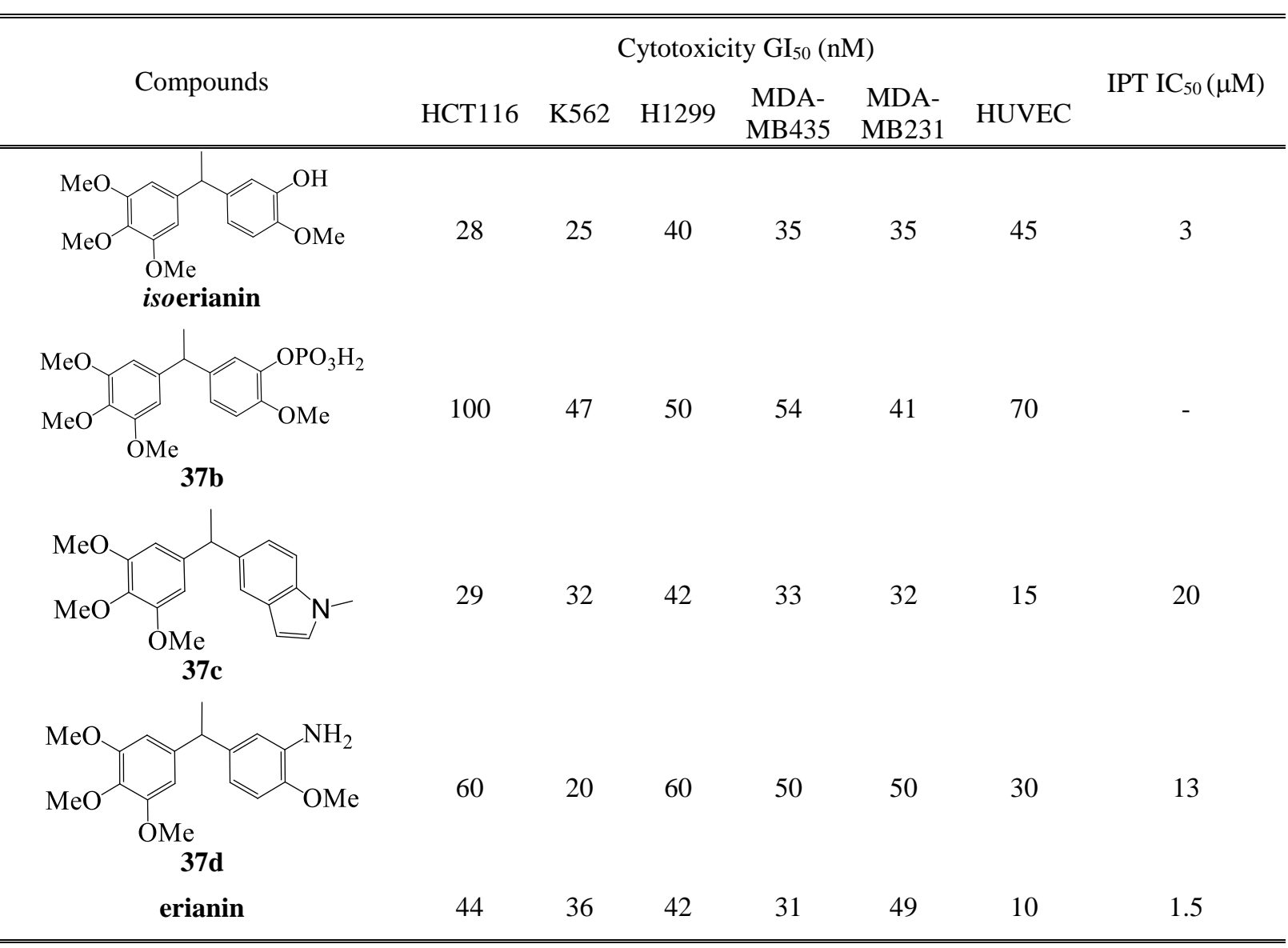


Figure 12. Effect of isoerianin on cell cycle distribution in K562 and H1299 cancer cell lines at $50 \mathrm{nM}$.
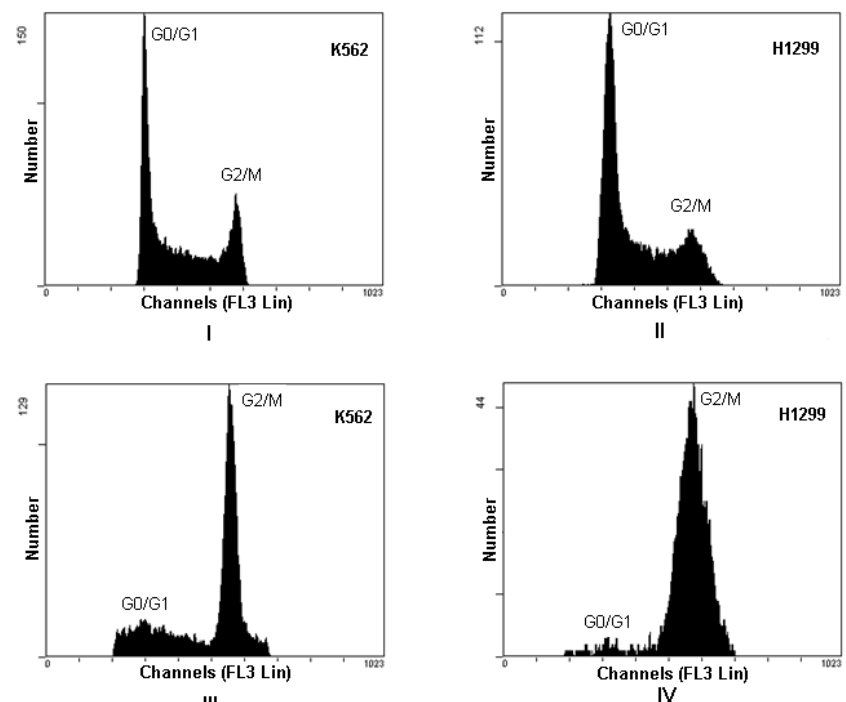

2.4.5.1.3 Effects on cell cycle distribution and apoptosis. We next investigated whether isoerianin influence the cell cycle in K562 and H1299 cells. As it was previously showed for isoCA-4 derivatives, treatment with isoerianin for $24 \mathrm{~h}$ at a concentration of $50 \mathrm{nM}$ blocked the cellular cycle in the $\mathrm{G}_{2} / \mathrm{M}$ phase in K562 and H1299 cell lines (Figure 12). Furthermore, we studied the effect of isoerianin, on the apoptosis induction in K562 and H1299 cells. After $24 \mathrm{~h}$ of treatment with isoerianin at a concentration of $50 \mathrm{nM}$, a pronounced processing of pro-caspases was observed (Figure 13). At this concentration, isoerianin was 4-fold more active as apoptosis inductor in H1299 than in apoptosis resistant-K562 cells.[66] Similarly, C3' $\mathrm{NH}_{2}$-derivative 36d activate efficiently the caspases family leading to apoptosis [93] (data not showed). These results show that the reduction of the ethylene double-bond present in isoCA-4 analogues had no deleterious impact on the apoptotic potent of such reduced-compounds $\mathbf{3 7}$.

Figure 13. Apoptotic effect of isoerianin in HCT1299 and K562 cells.

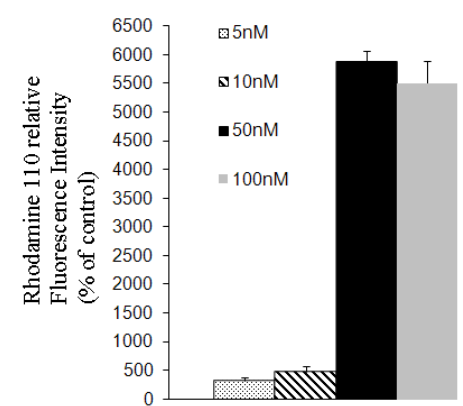

H1299 cells

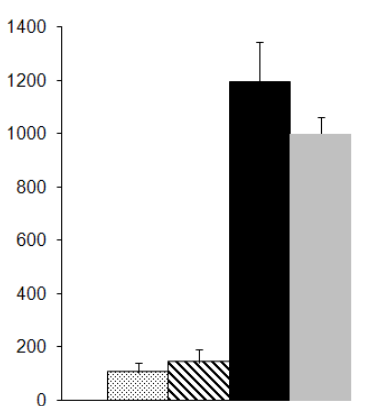

K562 cells

\subsection{Effect of isoerianin on HUVEC organization.}

The effect of isoerianin on HUVECs was next evaluated at a concentration of $1 \mu \mathrm{M}$. As observed in Figure 14, the tubes' structures were severely damaged when cells were exposed to isoerianin after $3 \mathrm{~h}$ of treatment. We found that isoerianin had equivalent activities in damaging vascular tubes at low concentrations than that of isoCA-4, isoFCA-4, iso $\mathrm{NH}_{2} \mathrm{CA}-4$ as well as benzil derivative 11d.

Figure 14. Effect of isoerianin on newly formed vessels.
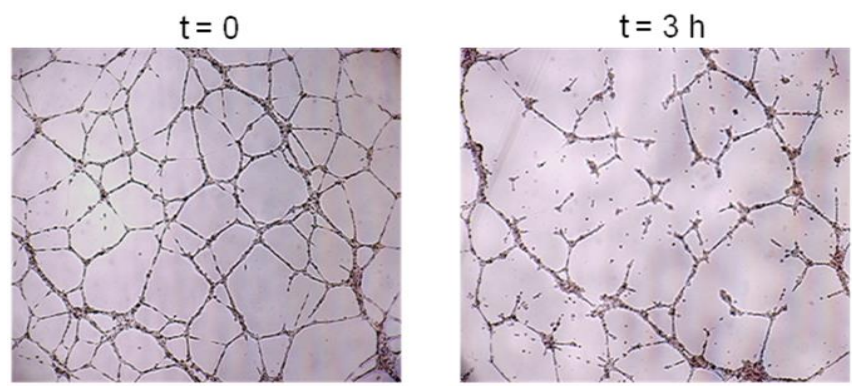

isoerianin $(1 \mu \mathrm{M})$ 


\subsubsection{C1-linker: diarylmethane derivatives 37 .}

We next designed a series of diarylmethane compounds of type $\mathbf{3 7}$ based on isoerianin to examine the effects regarding removal of the methyl substituent on the $\mathrm{C} 1$ linker. The synthesis of diarylmethane derivatives 37a-e is shown in Scheme 12.

Scheme 12. ${ }^{a}$ Synthesis of diarylmethanes 37.

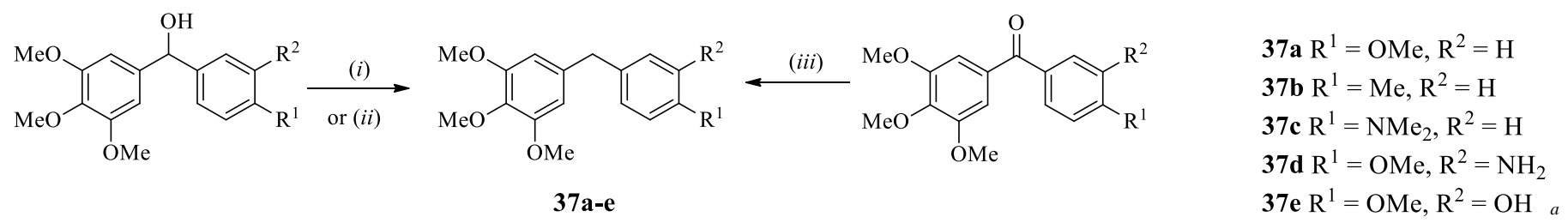

Reagents and conditions: (i) TfOH (20 mol\%), $i-\mathrm{PrOH}, 140{ }^{\circ} \mathrm{C}$, MWI. (ii) $\left(\mathrm{CH}_{3}\right)_{2} \mathrm{Cl}_{2} \mathrm{Si} / \mathrm{NaI}, 0{ }^{\circ} \mathrm{C}, \mathrm{CH}_{2} \mathrm{Cl}_{2}$. (iii) $\mathrm{NaBH}_{4}, \mathrm{TFA}, \mathrm{CH}_{2} \mathrm{Cl}_{2}, 25^{\circ} \mathrm{C}$.

Diarylmethanes 37 [40, 97, 98] were prepared from reduction of diarylcarbinols using either catalytic TfOH in $i$-PrOH [97] or dichloromethylsilane/sodium iodide [87] or by $\mathrm{NaBH}_{4}$-reduction of the aminophenstatin analogue. These diarylmethane derivatives were evaluated by an in vitro cytotoxicity assay which was carried out with a panel of human cancer cells. Unfortunately, all of these compounds were essentially not cytotoxic [93] and did not inhibit tubulin polymerization on the exception of phenol 37e $\left(\mathrm{IC}_{50}=2.3 \mu \mathrm{M}\right)$. [98] These results demonstrate that the replacement of the ethyl group in isoerianin or ethylene group in isoCA-4 by a methylene resulted in complete loss of cytotoxic activities indicating that and additionnal carbon atom $\left(\mathrm{sp}^{3}\right.$ or $\left.\mathrm{sp}^{2}\right)$ on $\mathrm{C} 1$ between the $\mathrm{A}$ - and B-rings is critical for cytotoxicity.

\section{Dihedral angles values between A- and B-rings and docking studies of bioactive analogues.}

\subsection{X-ray structures of isoCA-4 and isoerianin.}

Figure 15. X-ray structure of $i s o \mathrm{CA}-4$

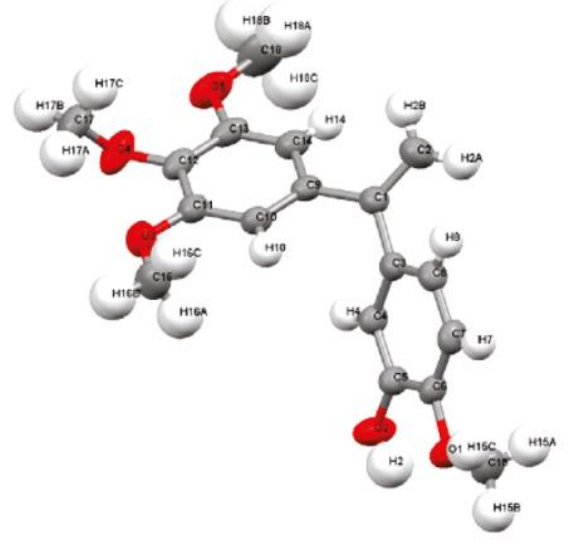

The high purity of isoCA-4 synthesized in our lab, enabled us to perform its X-ray structure determination. As shown in Figure 15, the X-ray crystallographic analysis for isoCA-4 revealed that the A- and B-rings are inclined toward each other with a dihedral angle of $68^{\circ}$. [54] It is of interest to note that, a similar non-planarity was observed with tubulin binding ligands as CA-4, CA-1 and colchicine in which the dihedral angle values are of $53^{\circ}[9,100], 66^{\circ}$ [101] and $53^{\circ}$ [102] respectively. Similarly, and according to X-ray structure, we also found that the dihedral angle between the two aromatic rings in isoerianin is of the same order of magnitude with a value of $77^{\circ}$ [93] (data not shown). These data and similar observations with efficient tubulin-binding ligands [103-105] indicate clearly that the conformational relationship of the A- and B-rings $\left(50^{\circ}<\right.$ dihedral angle $\left.<80^{\circ}\right)$ is an important component of ligand binding to $\beta$-tubulin on the colchicine binding-site. The presumptive binding mode of the most bioactive tubulin ligands (e.g. isoCA-4, isoerianin, dihydronaphtalene 30d, benzoxepin 32b and diarylethylenes 20c, 20h) and the dihedral angles values between diaryl groups are presented in Table 8 . 
Table 8. Docking-derived superimposition of the most bioactive ligands and dihedral angle values between diaryl groups.

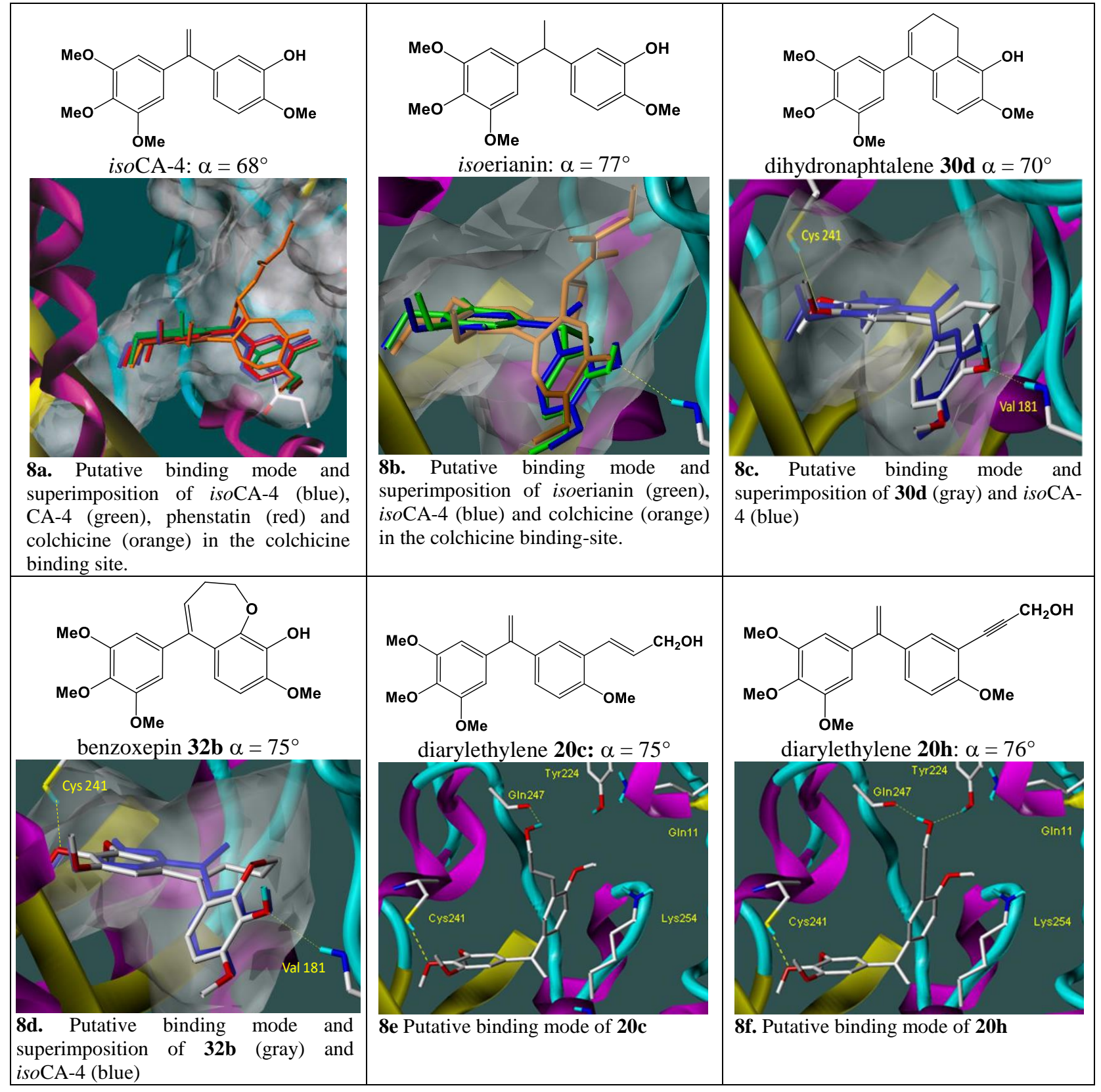

It is interesting to note that all of the selected ligands are structurally similar to CA-4 $\left(\alpha=53^{\circ}\right)$ and isoCA-4 $\left(\alpha=68^{\circ}\right)$ with comparable dihedral angle values ranging from $68^{\circ}$ to $77^{\circ}$. The presence of a $\sigma$-bond bridge in isoerianin $\left(\alpha=77^{\circ}\right)$ and the conformational restriction imposed to ligands by the formation of an additional ring $\left(\mathbf{3 0 d} \alpha=70^{\circ}\right)$ or heterocyclic system $(\mathbf{3 2 b} \alpha$ $=75^{\circ}$ ) does not modify significantly the dihedral angles between the A- and B-rings. As observed in figures 8a and 8b (Table 8), the superimposition of isoCA-4, isoerianin, and references CA-4, phenstatin and colchicine as they docked within the active site of $1 \mathrm{saO}$, illustrates the similar nature of positioning of the 3,4,5-trimethoxy substituents in A-ring and also 3-hydroxy-4-methoxy substituents (B-ring). Similarly, conformationally restricted isoCA-4 analogues such as dihydronaphtalene 30d and benzoxepin 32b show good superimposition with isoCA-4 with the trimethoxyphenyl ring in contact with Cys241 and with the 3-hydroxysubstituent of the B-ring which forms a hydrogen bond with Val181 as it was previously reported with other CA-4 analogues. [106-108] Contrary to the above situation where Val181 was important for binding in the colchicine-binding site of tubulin, the hydrogen bond with Val181 was not observed for compounds 20c and 20h bearing an alkenyl or alkynyl substituent on C3'position. Although the trimethoxyphenyl moiety remains anchored at the same place in proximity of Cys241, a polar cavity formed by Gln247, Tyr224, Gln11 and Lys254 accommodates the C3'-substituents of the B-ring. In details, 20c with the backbone carbonyl of Gln247, whereas alkynol 20h form a double hydrogen bond with Gln247 and Tyr224. Moreover, the 4'-methoxy 
group of each molecule attached to the B-ring is seen to establish an additional extra hydrogen bond with Lys254 (not displayed in figure 8e and 8f). These results indicate that, due to the replacement of the C3'-OH group of isoCA-4 by a larger alkenyl or alkynyl group in compounds $\mathbf{2 0 c}$ and $\mathbf{2 0 h}$, the position of the latter ligands is variously shifted in the tubulin binding-site without alteration for activity. Thus, it can be assumed that the large polar cavity formed by Gln247, Tyr224, Gln11 and Lys254 can accommodate a wide range of new ligands allowing to complete the SAR.

\section{Conclusions}

This review has provided the synthesis and in vitro assays of new CA-4 analogues developed in our group with non-isomerizable carbon-linkers of different sizes and SAR are summarized in Figure 16. In the C6 and C4 linker series, enediyne 4 and enyne derivatives 8-9 were found to be inactive with $\mathrm{GI}_{50}>1000 \mathrm{nM}$ and did not inhibit tubulin assembly significantly. In the C2 linker class, benzils 11c and 11d which strongly inhibited the cell growth at a nanomolar level (20 $\left.\mathrm{nM}<\mathrm{GI}_{50}<50 \mathrm{nM}\right)$ are the most promising derivatives. In addition to their cytotoxic effects against various cancer cells, benzils derivatives showed in vitro antivascular effects in HUVEC cells by disrupting tubes formation. These compounds were also potent inhibitors of tubulin assembly, with micromolar $\mathrm{IC}_{50}$ values, and arrested HCT116 and H1299 cells in the $\mathrm{G}_{2} / \mathrm{M}$ phase of the cell cycle. Moreover, a significant increase in proteolytic activity of caspase in cells treated with diketones 11c and 11d clearly demonstrates the potential of these drugs as apoptosis inductors.

Figure 16. SAR of combretastatin A-4 analogues having various C-linkers and advantages of isoCA-4.

\section{C6, C4 and C2 linkers:}

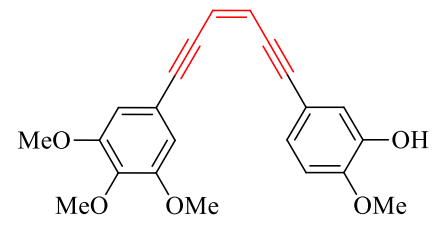

C6-linker: enediyne 4c inactive

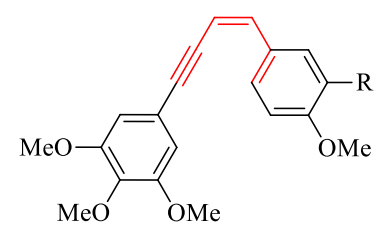

C4-linker: enediynes inactive
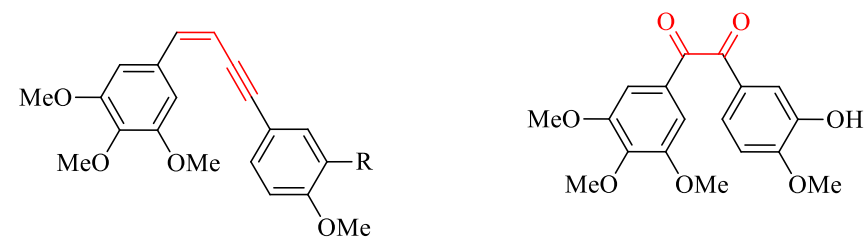

C2-linker: benzil 11c $\mathrm{GI}_{50}=25-40 \mathrm{nM}$ IPT $\mathrm{CI}_{50}=1.5 \mu \mathrm{M}$

\section{C1- linkers:}<smiles>COc1ccc2c(c1O)CCC=C2c1cc(OC)c(OC)c(OC)c1</smiles>

dihydronaphtalene 30d

$\mathrm{GI}_{50}=15-85 \mathrm{nM}$

IPT CI $50=2 \mu \mathrm{M}$<smiles>COc1ccc(C(C)c2cc(OC)c(OC)c(OC)c2)cc1O</smiles>

isoerianin

$\mathrm{GI}_{50}=25-45 \mathrm{nM}$

IPT CI $\mathrm{I}_{50}=3 \mu \mathrm{M}$<smiles>COc1ccc2c(c1O)OCCC=C2c1cc(OC)c(OC)c(OC)c1</smiles>

benzoxepin 32d

$\mathrm{GI}_{50}=1.5-8 \mathrm{nM}$

IPT CI $\mathrm{I}_{50}=3.8 \mu \mathrm{M}$<smiles>COc1ccc(Cc2cc(OC)c(OC)c(OC)c2)cc1O</smiles>

diarylmethane $37 \mathrm{e}$ inactive

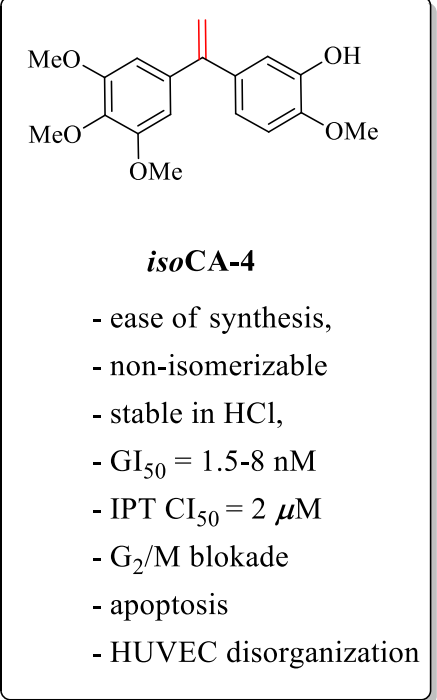

In the $\mathrm{C} 1$ linker series, after a detailed investigation of SAR, we found that 1,1-diarylethylene compounds 18-20 (isoCA-4 and analogues) as well as their reduced congeners isoerianin derivatives $\mathbf{3 6}$ were highly cytotoxic against a panel of cancer cells and 
inhibited the tubulin assembly at low concentrations. We also demonstrate that it is possible to lock the 1,1-ethylene bond of these derivatives in a dihydronaphthalene, chromene or benzoxepin ring with no significant loss of cytotoxicities. All of these nonisomerizable compounds including isoCA-4, isoerianin, dihydronaphtalene, chromene and benzoxepin derivatives, cause $\mathrm{G}_{2} / \mathrm{M}^{2}$ arrest and strongly induce apoptotic cell death in various cancer cell lines at low concentrations. In vitro antivascular effects of these drugs were tested using a human umbilical vein endothelial cell culture assay. Addition of these drugs to formed cords disrupted the integrity of the network after $3 \mathrm{~h}$ of treatment at doses which were not cytotoxic for such incubation time thereby demonstrating the anti-angiogenic effect of these new compounds.

For further in vivo investigations, we have selected as lead compound isoCA-4 which is the most active compound and which displays the largest structural simplicity. To the end, we first have recently demonstrated that isoCA-4 was poorly metabolized $(<10 \%)$ after incubation in human liver microsomal fractions. Seven phase I metabolites resulting mainly from O-demethylation and hydroxylation of the aromatic rings were identified, synthesized and evaluated. [109] All of these metabolites display a moderate level of cytotoxicity ( $\mathrm{GI}_{50}$ ranging from 35 to $2000 \mathrm{nM}$ ) and did not inhibit tubulin assembly, indicating that the antiproliferative properties of $i s o \mathrm{CA}-4$ are due to the parent drug itself since its metabolites are significantly less cytotoxic. Due to the poor water-solubility of isoCA-4 and to avoid the tedious preparation of phosphate-prodrugs, we envisioned to investigate the anticancer activity of isoCA-4 in vivo on the experimental LS174T human colon adenocarcinoma by incorporating isoCA-4 in squalenoyl nanoassemblies. [110] As it was previously observed with gemcitabine-squalene nanoparticules which was found to display improved anticancer activity, comparatively to gemcitabine free[111], we hope to increase the pharmacokinetic parameters and the biodistribution, [112] as well as an improved intracellular penetration. These results will be published in due course.

\section{Conflict Of Interest}

\section{None}

\section{Acknowledgement:}

The CNRS (Centre National de la Recherche Scientifique) and the MRES (Ministère de la Recherche et de l'Enseignement Supérieur) are gratefully acknowledged for financial support of this research. Our laboratory BioCIS-UMR 8076 is a member of the Laboratory of Excellence LERMIT supported by a grant from ANR (Agence Nationale de la Recherche, ANR-10-LABX-33). The work on tubulin was supported by a grant from ANR (ANR-09-BLAN-0071).

\section{None}




\section{Abbreviations}

\section{Miscellaneous}

VDAs

CA-4

ITP

$\mathrm{IC}_{50}$

$\mathrm{GI}_{50}$

MDR

rt

DNA

HPLC

PCC

PTSA

DMSO

DDQ

HCT

SH-SY5Y

MCF7

CA-46

K562

MCF7R

K562

H1299

A549

MDA-MB-435

MDA-MB-231

U87

NCI-H460

DU-145

SK-OV-3

CEM

HBL100

NCI-H460

LS174T

HUVEC
Vascular disrupting agents

Combretastatin A-4

Inhibition of tubulin polymerization

Concentration of compound required to inhibit $50 \%$ of the rate of microtubule polymerization

Concentration of compound needed to reduce cell growth by $50 \%$

Multi-drugs resistant

Room temperature

Desoxyribonucleic acid

High Performance Liquid Chromatography

\section{Chemistry}

Pyridinium chlorochromate

Para-toluenesulfonic acid

Dimethyl sulfoxide

2,3-Dichloro-5,6-dicyanobenzoquinone

\section{Cancer Cells}

Human colon tumor

Neuroblastoma

Human breast carcinoma

Burkitt lymphoma

Human cervical carcinoma

Multidrug resistant human breast cancer

Chronic mylogenous leukemia

Non small lung human carcinoma

Carcinomic alveolar basal epithelial

Breast cancer

Hormone-independent breast cancer

Glioblastoma

Non small lung human carcinoma

Human prostate cancer

Human ovarian carcinoma

Leukemia cells

Human epithelial mammary cells

Human non-small lung cancer cells

Human colon adenocarcinoma

Human umbilical vein endothelial cells 
[1] Pettit, G.; Singh, S.B.; Hamel, E.; Lin, C.M.; Alberts, D.S.; Garcia-Kendall, D. Isolation and structure of the strong cell growth and tubulin inhibitor combretastatin A-4. Experientia, 1989, 45, 209-211.

[2] Sackett, D.L. Podophyllotoxin, steganacin and combretastatin: natural products that bind at the colchicine site of tubulin. Pharmacol. Ther., 1993, 59, 163-228.

[3] Xia, Y.; Yang, Z.-Y.; Xia, P.; Bastow, K.F.; Tachibana, Y.; Kuo, S.-C.; Hamel, E.; Hackl, T.; Lee, K.-H. Antitumor agents. 181. Synthesis and biological evaluation of 6,7,2',3',4'-substituted-1,2,3,4-tetrahydro-2-phenyl-4-quinolones as a new class of antimitotic antitumor agents. J. Med. Chem., 1998, 41, 1155-1162.

[4] Mc Gown, A.T.; Fox, B.W. Differential cytotoxicity of combretastatins A1 and A4 in two daunorubucin-resistant P388 cell lines. Cancer Chemother. Pharmacol. 1990, 26, 79-81.

[5] Dark, G.G.; Hill, S.A.; Prise, V.E.; Tozer, G.M.; Pettit, G.R.; Chaplin, D.J. Combretastatin A-4, an agent that displays potent and selective toxicity toward tumor vasculature. Cancer Res., 1997, 57, 1829-1834.

[6] Griggs, J. Metcalfe J.C., Hesketh, R. Targeting tumour vasculature: the development of combretastatin A4. Lancet Oncol., 2001, 2, 82-87.

[7] Ohsumi, K. Nakagawa, R. Fukuda, Y. Hatanaka, T. Morinaga, Y. Nihei, Y. Ohishi, K. Suga, Y. Akiyama, Y., Tsuji, T. Novel combretastatin analogues effective against murine solid tumors: design and structure-activity relationships. $J$. Med. Chem. 1998, 41, 3022-3032.

[8] Pettit, G.R. Toki, B.E. Herald, D.L. Boyd, M.R. Hamel, E. Pettit R.K., Chapuis, J.-C. Antineoplastic agents. 410. Asymmetric hydroxylation of trans-combretastatin A-4. J. Med. Chem. 1999, 42, 1459-1465.

[9] Pettit, G.R.; Rhodes, M.R.; Herald, D.L.; Chaplin, D.J.; Stratford, M.R.; Hamel, E.; Pettit, R.K.; Chapuis, J.-C.; Oliva, D. Antineoplastic agents 393. Synthesis of the trans-isomer of combretastatin A-4 prodrug. Anti-Cancer Drug Des., 1998, 13, 981-993.

[10] Aprile, S. Del Grosso, E. Tron G.C., Grosa, G. In vitro metabolism study of combretastatin A-4 in rat and human liver microsomes. Drug Metab. Dispos., 2007, 35, 2252-2261.

[11] Galbraith, S.M.; Maxwell, R.J.; Lodge, M.A. Combretastatin A4 phosphate has tumor antivascular activity in rat and man as demonstrated by dynamic magnetic resonance imaging. J. Clin. Oncol., 2003, 21, 2831-2842.

[12] Anderson, H.L.; Yap, J.T.; Miller, M.P.; Robbins, A.; Jones, T.; Price, P.M. Assessment of pharmacodynamic vascular response in a phase I trial of combretastatin A4 phosphate. J. Clin. Oncol., 2003, 21, 2828-2830.

[13] Ohno, T.; Kawano, K.; Sasaki, A.; Aramaki, M.; Tahara, K.; Etoh, T.; Kitano, S. Antitumor and antivascular effects of AC-7700, a combretastatin A-4 derivative, against rat liver cancer. Int. J. Clin. Oncol., 2002, 7, 171-176.

[14] Banerjee, S.; Wang, Z.; Mohammad, M.; Sarkar, F.H.; Mohammad, R.M. Efficacy of selected natural products as therapeutic agents against cancer. J. Nat. Prod., 2008, 71, 492-496.

[15] Rustin, G.J.; Galbraith, S.; Anderson, H.; Stratford, M.; Folkes, L.K.; Sena, L.; Gumbrell, L.; Price, P.M. Phase I clinical trial of weekly combretastatin A4 phosphate: clinical and pharmacokinetic results. J. Clin. Oncol., 2003, 21, $2815-2822$.

[16] Nam, N.H. Combretastatin A-4 analogues as antimitotic antitumor agents. Curr. Med. Chem., 2003, 10, 1697-1722 and references therein.

[17] Tron, G.C.; Pirali, T.; Sorba, G.; Pagliai, F.; Busacca, S.; Genazzani, A.A. Medicinal chemistry of combretastatin A4: present and future directions. J. Med. Chem., 2006, 49, 3033-3044.

[18] Pattillo, C.B. Combretastatin derivatives in cancer: recent research reviewed. Drugs Fut., 2011, 36, 385-390.

[19] Cirla, A.; Mann, J. Combretastatins: from natural products to drug discovery. Nat. Prod. Rep., 2003, 20, 558-564.

[20] Shan, Y.; Zhang, J.; Liu, Z.; Wang, M.; Dong, Y. Developments of combretastatin A-4 derivatives as anticancer agents. Curr. Med. Chem., 2011, 18, 523-538.

[21] Marelli, M.; Conforti, F.; Statti, G.A.; Cachet, X.; Michel, S.; Tillequin, F.; Menichini, F. Biological potential and structure-activity relationships of most recently developed vascular disrupting agents: an overview of new derivatives of natural combretastatin A-4.Curr. Med. Chem. 2011, 18, 3035-3081.

[22] Cushman, M.; Nagarathnam, D.; Gopal, D.; Chakraborti, A.K.; Lin, C.; Hamel, E. Synthesis and evaluation of stilbene and dihydrostilbene derivatives as potential anticancer agents that inhibit tubulin polymerization J. Med. Chem., 1991, $34,2579-2588$.

[23] Lawrence, N.J.; Rennison, D.; Woo, M.; McGown, A.T.; Hadfield, J.A. Antimitotic and cell growth inhibitory properties of combretastatin A-4-like ethers. Bioorg. Med. Chem. Lett., 2001, 11, 51-54.

[24] Giraud, A; Provot, O.; Hamze, A.; Brion, J.D.; Alami, M. One-pot hydrosilylation-protodesilylation of functionalized diarylalkynes: a highly selective access to Z-stilbenes. Application to the synthesis of combretastatin A-4. Tetrahedron Lett., 2008, 49, 1107-1110.

[25] Provot, O.; Giraud, A.; Peyrat, J.F.; Alami, M.; Brion, J.D. Synthetic approach to enyne and enediyne analogues of anticancer agents. Tetrahedron Lett., 2005, 46, 8547-8550.

[26] Smith, A.L.; Nikolaou, K.C. The enediyne antibiotics. J. Med. Chem. 1996, 39, 2103-2017.

[27] Sonogashira, K. Tohda, Y., Hagihara, N. A convenient synthesis of acetylenes: catalytic substitutions of acetylenic hydrogen with bromoalkenes, iodoarenes and bromopyridines. Tetrahedron Lett., 1975, 4467-4470.

[28] Alami, M. Ferri F., Linstrumelle, G. An Efficient palladium-catalysed reaction of vinyl and aryl halides or triflates with terminal alkynes. Tetrahedron Lett. 1993, 34, 6403-6406.

[29] Alami, M.; Peyrat, J.F., Brion, J.D. 1,2-Dihalogenalkenes: Useful Linchpins to Unsaturated Compounds via Palladium or Nickel Catalysis. Synthesis, 2000, 1499-1518. 
[30] Alami, M.; Ferri, F.; Gaslain, Y. A two-step synthesis of terbinafine. Tetrahedron Lett., 1996, $37,57-58$.

[31] Alami, M.; Crousse, B.; Ferri, F. Weakly Ligated Palladium Complexes $\mathrm{PdCl}_{2}(\mathrm{RCN})_{2}$ in Piperidine: Versatile Catalysts for Sonogashira Reaction of Vinyl Chlorides at Room Temperature. J. Organomet. Chem. 2001, 624, 114-123.

[32] Lo, Y.H.; Lin, C.C.; Lin, C.F.; Lin, Y.T.; Hong, Y.R.; Yang, S.H.; Lin, S.R.; Yang, S.C.; Chang, L.S.; Wu, M.J. 2-(6aryl-3(Z)-hexen-1,5-diynyl)anilines as a new class of potent antitubulin agents. J. Med. Chem., 2008, 51, $2682-2688$.

[33] Alami, M.; Ramiandrasa, P.; Cahiez, G. Manganese Halides-Catalyzed Selective Cross Coupling Reaction of Unsaturated Vinyl Chlorides with Grignard Reagents. Synlett, 1998, 325-327.

[34] Peyrat, J.-F.; Thomas, E.; L’Hermite, N.; Alami, M.; Brion, J.-D. Versatile palladium(II)-catalyzed Negishi coupling reactions with functionalized conjugated alkenyl chlorides. Tetrahedron Lett., 2003, 44, 6703-6707.

[35] Seck, M.; Franck, X.; Hocquemiller, R.; Figadère, B.; Peyrat, J.F.; Provot, O.; Brion, J.D.; Alami, M. Synthesis of substituted quinolines by iron-catalyzed coupling reactions between chloroenynes and Grignard reagents. Tetrahedron Lett., 2004, 45, 1881-1884.

[36] Dos Santos, M.; Franck, X.; Hocquemiller, R.; Figadère, B.; Peyrat, J.F.; Provot, O.; Brion, J.D.; Alami, M. IronCatalyzed Coupling Reaction between 1,1-Dichloro-1-alkenes and Grignard Reagents. Synlett, 2004, 15, $2697-2700$.

[37] Kaffy, J.; Pontikis, R.; Florent, J.C.; Monneret, C. Synthesis and biological evaluation of vinylogous combretastatin A-4 derivatives. Org. Biomol. Chem., 2005, 3, 2657-2660.

[38] Pettit, G. R.; Toki, B.; Herald, D. L.; Verdier-Pinard, P.; Boyd, E.; Hamel, M. R.; Pettit, R. K. Antineoplastic agents. 379. Synthesis of phenstatin phosphate. J. Med. Chem., 1998, 41, 1688-1695.

[39] Liou, J.P.; Chang, C.W.; Song, J.-S.; Yang, Y.N.; Yeh, C.F.; Tseng, H.Y.; Lo, Y.K.;. Chang, Y.L; Chang, C.M.; Hsieh, H.P. Synthesis and structure-activity relationship of 2 -aminobenzophenone derivatives as antimitotic agents. J. Med. Chem., 2002, 45, 2556-2562.

[40] Liou, J.P.; Chang, J.Y.; Chang, C.W.; Chang, C.Y.; Mahindroo, N.; Kuo, F.M.; Hsieh, H.P. Synthesis and structureactivity relationships of 3-aminobenzophenones as antimitotic agents. J. Med. Chem., 2004, 47, 2897-2905.

[41] Ducki, S.; Hadfield, J.A.; Lawrence, N.J.; Liu, C.Y.; McGown, A.T.; Rennison, D. Potent antimitotic and cell growth inhibitory properties of substituted chalcones. Bioorg. Med. Chem. Lett., 1998, 8, 1051-1056.

[42] Lawrence, N.J.; McGown, A.T.; Ducki, S.; Hadfield, J.A. The interaction of chalcones with tubulin. Anti-Cancer Drug Des., 2000, 15, 35-41.

[43] Ducki, S.; Mackenzie, G.; Greedy, B.; Armitage, S.; Fournier Dit Chabert, J.; Bennett, E.; Nettles, J.; Snyder, J.P.; Lawrence, N.J. Combretastatin-like chalcones as inhibitors of microtubule polymerisation. Part 2: Structure-based discovery of alpha-aryl chalcones. Bioorg. Med. Chem., 2009, 17, 7711-7722.

[44] Giraud, A.; Provot, O.; Peyrat, J.F.; Alami, M.; Brion, J.D. Microwave-assisted efficient synthesis of 1,2-diaryldiketones: a novel oxidation reaction of diarylalkynes with DMSO promoted by $\mathrm{FeBr}_{3}$. Tetrahedron, 2006, 62, 7667-7673.

[45] Mousset, C.; Provot, O.; Hamze, A.; Bignon, J.; Brion, J.D.; Alami, M. DMSO-PdI2 as a powerful oxidizing couple of alkynes into benzils: one-pot synthesis of nitrogen-containing five- or six-membered heterocycles. Tetrahedron, 2008, 64, 4287-4294.

[46] Mousset, C.; Giraud, A.; Provot, O.; Hamze, A.; Bignon, J.; Liu, J.M.; Thoret, S.; Dubois, J.; Brion, J.D.; Alami, M. Synthesis and antitumor activity of benzils related to combretastatin A-4. Bioorg. Med. Chem. Lett., 2008, 18, $3266-3271$.

[47] Lin, C.M.; Ho, H.H.; Pettit, G.R.; Hamel, E. Antimitotic natural products combretastatin A-4 and combretastatin A-2: studies on the mechanism of their inhibition of the binding of colchicine to tubulin. Biochemistry, 1989, 28, 6984-6991.

[48] Pettit, G.R.; Temple, C., Jr.; Narayanan, V.L.; Varma, R.; Boyd, M.R.; Rener, G.A.; Bansal, N. Antineoplastic agents 322. synthesis of combretastatin A-4 prodrugs. Anticancer Drug Des., 1995, 10, 299-309.

[49] Boatright, K.M.; Salvesen, G.S. Mechanisms of caspase activation. Curr. Opin. Cell. Biol., 2003, 15, 725-731.

[50] Pettit, G.R.; Singh, S.B.; Boyd, M.R.; Hamel, E.; Pettit, R.K.; Schmidt, J.M.; Hogan, F. Antineoplastic agents. 291. Isolation and synthesis of combretastatins A-4, A-5, and A-6(1a). J. Med. Chem. 1995, 38, 1666-1672.

[51] Lin, C.M.; Singh, S.B.; Chu, P.S.; Dempcy, R.O.; Schmidt, J.M.; Pettit, G.R.; Hamel, E. Interactions of tubulin with potent natural and synthetic analogs of the antimitotic agent combretastatin: a structure-activity study. Mol. Pharmacol., 1988, 34, 200-208.

[52] Gong, Y.-Q.; Fan, Y., Wu, D.Z.; Yang, H.; Hu, Z.-B.; Wang, Z.-T. In vivo and in vitro evaluation of erianin, a novel antiangiogenic agent. Eur. J. Cancer, 2004, 40, 1554-1565.

[53] Shirai, R.; Tokuda, K.; Koiso, Y.; Shigeo, I. Synthesis and nti-tubulin activity of aza-combretastatins. Bioorg. Med. Chem. Lett., 1994, 4, 699-704.

[54] Messaoudi, S.; Tréguier, B.; Hamze, A.; Provot, O.; Peyrat, J.F.; Rodrigo De Losada, J.; Liu, J.M.; Bignon, J.; Wdzieczak-Bakala, J.; Thoret, S.; Dubois, J.; Brion, J.D.; Alami, M. Isocombretastatins-A versus combretastatins-A: the forgotten isoCA-4 isomer as a highly promising cytotoxic and antitubulin agent. J. Med. Chem., 2009, 52, 4538-4542.

[55] Barluenga, J.; Moriel, P.; Valdés, C.; Aznar, F. N-Tosylhydrazones as Reagents for Cross-Coupling Reactions: A Route to Polysubstituted Olefins. Angew. Chem., Int. Ed., 2007, 46, 5587-5590.

[56] Tréguier, B.; Hamze, A.; Provot, O.; Brion, J.D.; Alami, M. Expeditious synthesis of 1,1-diarylethylenes related to isocombretastatin A-4 (isoCA-4) via palladium-catalyzed arylation of N-tosylhydrazones with aryl triflates. Tetrahedron Lett., 2009, 50, 6549-6552.

[57] Hamze, A.; Veau, D.; Provot, O.; Brion, J.D.; Alami, M. Palladium-catalyzed Markovnikov terminal arylalkynes hydrostannation: application to the synthesis of 1,1-diarylethylenes. J. Org. Chem., 2009, 74, 1337-1340.

[58] Hamze, A.; Giraud, A.; Messaoudi, S.; Provot, O.; Peyrat, J.F.; Bignon, J.; Liu, J.M.; Wdzieczac-Bakala, J.; Thoret, S.; Dubois, J.; Brion, J.D.; Alami, M. Synthesis, biological evaluation of 1,1-diarylethylenes as a novel class of antimitotic agents. ChemMedChem, 2009, 4, 1912-1924. 
[59] Nakamura, H.; Kuroda, H.; Saito, H.; Suzuki, R.; Yamori, T.; Maruyama, K.; Haga, T. Synthesis and biological evaluation of boronic acid containing cis-stilbenes as apoptotic tubulin polymerization inhibitors. ChemMedChem, 2006, $1,729-740$.

[60] Pinney, K.G.; Mejia, M.P.; Villalobos, V.M.; Rosenquist, B.E.; Pettit, G.R. Synthesis and biological evaluation of aryl azide derivatives of combretastatin a-4 as molecular probes for tubulin. Bioorg. Med. Chem., 2000, 8, 2417-2425.

[61] Hamze, A.; Rasolofonjatovo, E.; Provot, O.; Mousset, C.; Veau, D.; Rodrigo, J.; Bignon, J.; Liu, J.M.; WdzieczakBakala, J.; Thoret, S.; Dubois, J.; Brion, J.D.; Alami, M. B-Ring-modified isocombretastatin A-4 analogues endowed with interesting anticancer activities. ChemMedChem, 2011, 6, 2179-2191.

[62] Olivi, N.; Thomas, E.; Peyrat, J.F.; Alami, M.; Brion, J.D. Highly Efficient p-Toluenesulfonic Acid-Catalyzed Alcohol Addition or Hydration of Unsymmetrical Arylalkynes. Synlett, 2004, 2175-2179.

[63] Le Bras, G.; Provot, O.; Peyrat, J.F.; Brion, J.D.; Alami, M. Rapid microwave assisted hydration of internal arylalkynes in the presence of PTSA: an efficient regioselective access to carbonyl compounds. Tetrahedron Lett., 2006, 47, 54975501 .

[64] Jacubert, M.; Hamze, A.; Provot, O.; Peyrat, J.F.; Brion, J.D.; Alami, M. p-Toluenesulfonic acid-mediated cyclization of o-(1-alkynyl)anisoles or thioanisoles: synthesis of 2-arylsubstituted benzofurans and benzothiophenes. Tetrahedron Lett., 2009, 50, 3588-3592.

[65] Jacubert, M.; Provot, O.; Peyrat, J.F.; Hamze, A.; Brion, J.D.; Alami, M. p-Toluenesulfonic acid-promoted selective functionalization of unsymmetrical arylalkynes: a regioselective access to various arylketones and heterocycles. Tetrahedron, 2010, 66, 3775-3787.

[66] Chang, M.P.; Bramhall, J.; Graves, S.; Bonavida, B.; Wisnieski, B.J. Internucleosomal DNA cleavage precedes diphtheria toxin-induced cytolysis. Evidence that cell lysis is not a simple consequence of translation inhibition. J. Biol. Chem., 1989, 264, 15261-15267.

[67] McGahon, A.; Bissonnette, R.; Schmitt, M.; Cotter, K.M.; Green, D.R.; Cotter, T.G. BCR-ABL maintains resistance of chronic myelogenous leukemia cells to apoptotic cell death. Blood, 1994, 83, 1179-1187.

[68] McGahon, A.J.; Nishioka, W.K.; Martin, S.J.; Mahboubi, A.; Cotter, T.G.; Green, D.R. Regulation of the Fas apoptotic cell death pathway by Abl. J. Biol. Chem., 1995, 270, 22625-22631.

[69] Gangemi, R.M. Tiso, M. Marchetti, C. Severi, A.B. Fabbi, M. Taxol cytotoxicity on human leukemia cell lines is a function of their susceptibility to programmed cell death. Cancer Chemother. Pharmacol., 1995, 36, 385-392.

[70] Dubrez, L. Goldwasser, F. Genne, P. Pommier, Y. Solary, E. The role of cell cycle regulation and apoptosis triggering in determining the sensitivity of leukemic cells to topoisomerase I and II inhibitors. Leukemia, 1995, 9, 1013-1024.

[71] Ray, S. Bullock, G. Nunez, G. Tang, C. Ibrado, A. M. Huang, Y. Bhalla, K. Enforced expression of Bcl-XS induces differentiation and sensitizes chronic myelogenous leukemia-blast crisis K562 cells to 1-beta-Darabinofuranosylcytosine-mediated differentiation and apoptosis. Cell Growth Diff., 1996, 7, 1617-1623.

[72] Aziz, J. ; Brachet, E.; Hamze, A.; Peyrat, J.F.; Bernadat, G.; Morvan, E.; Bignon, J.; Wdzieczak-Bakala, J.; Desravines, D.; Dubois, J.; Tueni, M.; Yassine, A.; Brion, J.D.; Alami, M. Synthesis, biological evaluation, and structure-activity relationships of tri- and tetrasubstituted olefins related to isocombretastatin A-4 as new tubulin inhibitors. Org. Biomol. Chem. 2013, 11, 430-442.

[73] Bekaert, A.; Provot, O.; Rasolojahona, O.; Alami, M.; Brion, J.D. N-Methylpyrrolidin-2-one hydrotribromide (MPHT) a mild reagent for selective bromination of carbonyl compounds: synthesis of substituted 2-bromo-1-naphtols. Tetrahedron Lett., 2005, 46, 4187-4191.

[74] Jacubert, M.; Tikad, A.; Provot, O.; Hamze, A.; Brion, J.D.; Alami, M. MPHT promoted bromocyclization of orthosubstituted arylalkynes: Application to the synthesis of 2-substituted-3-bromo-benzofurans and benzo[b]thiophenes. Eur. J. Org. Chem. 2010, 4492-4500.

[75] Giordano, C.; Castaldi, G.; Casagrande, F.; Abis, L. Silver assisted rearrangement of primary and secondary $\alpha$-bromoalkylarylketones. Tetrahedron Lett., 1982, 23, 1385-1386.

[76] Brachet, E.; Hamze, A.; Peyrat, J.F.; Brion, J.D.; Alami, M. Pd-catalyzed reaction of sterically hindered hydrazones with aryl halides: synthesis of tetra-substituted olefins related to iso-combretastatin A-4. Org. Lett., 2010, 12, 4042-4045.

[77] Rasolofonjatovo, E.; Provot, O.; Hamze, E.; Bignon, J.; Thoret, S.; Brion, J.D.; Alami, M. Regioselective hydrostannation of diarylalkynes directed by a labile ortho bromine atom: An easy access to stereodefined triarylolefins, hybrids of combretastatin A-4 and isocombretastatin A-4. Eur. J. Med. Chem., 2010, 45, 3617-3626.

[78] Liron, F.; Le Garrec, P.; Alami, M. Regiochemical Control in the Hydrostannylation of Aryl-Substituted Alkynes. A Stereoselective Synthesis of Disubstituted Vinylstannanes. Synlett, 1999, 246-248.

[79] Alami, M.; Liron, F.; Gervais, M.; Peyrat, J.F.; Brion, J.D. Ortho substituents direct regioselective addition of tributyltin hydride to unsymmetrical diaryl (or heteroaryl) alkynes: an efficient route to stannylated stilbene derivatives. Angew. Chem., Int. Ed., 2002, 41, 1578-1580.

[80] Hamze, A.; Provot, O.; Brion, J.D.; Alami, M. Regiocontrol of the palladium-catalyzed tin hydride addition to Z-enynols: remarkable Z-directing effects. J. Org. Chem., 2007, 72, 3868-3874.

[81] Ferri, F.; Alami, M. Expeditious stereo and regioselective synthesis of stannylated dienynes: Versatile precursors of dienediynes related to neocarzinostatin chromophore. Tetrahedron Lett., 1996, 37, 7971-7974.

[82] Hamze, A.; Le Menez, P.; Provot, O.; Morvan, E.; Brion, J.D.; Alami, M. Regioselective hydrostannation of highly hindered arylalkynes under ortho-directing effects. Tetrahedron Lett., 2010, 66, 8698-8706.

[83] Hamze, A.; Provot, O.; Brion, J.D.; Alami, M. Regiochemical Aspects of the Platinum Oxide Catalyzed Hydrosilylation of Alkynes. Synthesis, 2007, 2025-2036.

[84] Liron, F.; Gervais, M.; Peyrat, J.F.; Alami, M.; Brion, J.D. Palladium-catalyzed stereoselective synthesis of E- and Z-1,1diaryl or triarylolefins. Tetrahedron Lett.; 2003, 44, 2789-2794. 
Bailly, C.; Bal, C.; Barbier, P.; Combes, S.; Finet, J.P.; Hildebrand, M.P.; Peyrot, V.; Wattez, N. Synthesis and biological evaluation of 4-arylcoumarin analogues of combretastatins. J. Med. Chem., 2003, 46, 5437-5444.

[86] Ganina, O.G.; Daras, E.; Bourgarel-Rey, V.; Peyrot, V.; Andresyuk, A.N.; Finet, J.P.; Fedorov, A.Y.; Beletskaya, I.P.; Combes, S. Synthesis and biological evaluation of polymethoxylated 4-heteroarylcoumarins as tubulin assembly inhibitor. Bioorg. Med. Chem., 2008, 16, 8806-8812.

[87] Sriram, M.; Hall, J.J.; Grohmann, N.C.; Strecker, T.E.; Wootton, T.; Franken, A.; Trawick, M.L.; Pinney, K. Design, synthesis and biological evaluation of dihydronaphthalene and benzosuberene analogs of the combretastatins as inhibitors of tubulin polymerization in cancer chemotherapy. Bioorg. Med. Chem., 2008, 16, 8161-8171.

[88] Rasolofonjatovo, E.; Provot, O.; Hamze, A.; Rodrigo, J.; Bignon, J.; Wdzieczak-Bakala, J.; Desravines, D.; Dubois, J.; Brion, J.D.; Alami, M. Conformationnally restricted naphthalene derivatives type isocombretastatin A-4 and isoerianin analogues: Synthesis, cytotoxicity and antitubulin activity. Eur. J. Med. Chem., 2012, 52, $22-32$.

[89] Messaoudi, S.; Brion, J.D.; Alami, M. An Expeditious Copper-Catalyzed Access to 3-Aminoquinolinones, 3Aminocoumarins and Anilines using Sodium Azide. Adv. Synth. Catal., 2010, 352, 1677-1687.

[90] Anderson, K.; Ikawa, T.; Tundel, R.E.; Buckwald, S.L. The Selective Reaction of Aryl Halides with KOH: Synthesis of Phenols, Aromatic Ethers and Benzofurans. J. Am. Chem. Soc., 2006, 128, 10694-10695.

[91] K.G. Pinney, V.P. Mocharla, Z. Chen, C.M. Garner, A. Ghatak, M. Hadimani, J. Kessler, J.M. Dorsey, K. Edvardsen, D.J. Chaplin, J. Prezioso, U.R. Ghatak U.S. Patent Appl. Publ. 2004, 20040043969 A1.

[92] Rasolofonjatovo, E.; Provot, O.; Hamze, A.; Rodrigo, J.; Bignon, Wdzieczak-Bakala, J.; Lenoir, C.; Desravines, D.; Dubois, J.; Brion, J.D.; Alami, M. Design, synthesis and anticancer properties of 5-arylbenzoxepins as conformationally restricted isocombretastatin A-4 analogs. Eur. J. Med. Chem., 2013, 62, 28-39.

[93] Messaoudi, S.; Hamze, A.; Provot, O.; Tréguier, B.; Rodrigo De Losada, J.; Bignon, J.; Liu, J.M.; Wdzieczak-Bakala, J.; Thoret, S.; Dubois, J.; Brion, J.D.; Alami, M. Discovery of isoerianin analogues as promising anticancer agents. ChemMedChem, 2011, 6, 488-497.

[94] Gong, Y.Q.; Fan, Y.; Wu, D.Z.; Yang, H.; Hu, Z.B.; Wang, Z.T. In vivo and in vitro evaluation of erianin, a novel antiangiogenic agent. Eur. J. Cancer, 2004, 40, 1554-1565.

[95] Schilstra, M.J.; Martin, S.R.; Bayleys, P.M. The effect of podophyllotoxin on microtubule dynamics. J. Biol. Chem., 1989, 264, 8827-8834.

[96] Jordan, M.A.; Thrower, D.; Wilson, L. Effects of vinblastine, podophyllotoxin and nocodazole on mitotic spindles. Implications for the role of microtubule dynamics in mitosis. J. Cell. Sci., 1992, 102, 401-416.

[97] L'Hermite, N.; Giraud, A.; Provot, O.; Peyrat, J.F.; Alami, M.; Brion, J.D. Disproportionation reaction of diarylmethylisopropyl ethers: a versatile access to diarylmethanes from diarylcarbinols speeded up by the use of microwave irradiation. Tetrahedron, 2006, 62, 11994-12002.

[98] Getahun, Z.; Jurd, L.; Chu, P.S.; Lin, C.M.; Hamel, E. Synthesis of alkoxy-substituted diaryl compounds and correlation of ring separation with inhibition of tubulin polymerization: differential enhancement of inhibitory effects under suboptimal polymerization reaction conditions. J. Med. Chem., 1992, 35, 1058-1067.

[99] Wiggins, J.M. A convenient procedure for the reduction of diarylmethanols with dichlorodimethylsilane/sodium iodide. Synth. Commun., 1988, 18, 741-749.

[100] Lara-Ochoa, F.; Espinosa-Perez, G. A new synthesis of combretastatins A-4 and AVE-8062A. Tetrahedron Lett., 2007, 48, 7007-7010.

[101] Pettit, G.R.; Singh, S.B.; Niven, M.L.; Hamel, E.; Schmidt, J.M. Isolation, structure, and synthesis of combretastatins A-1 and B-1, potent new inhibitors of microtubule assembly, derived from Combretum caffrum. J. Nat. Prod., 1987, 50, 119131.

[102] Dietrich, H.W.,III; Wiliams, R.C., Jr.; Macdonald, T.L.; Wilson, L.; Puett, D. Changes in the circular dichroic spectrum of colchicine associated with its binding to tubulin. Biochemistry, 1981, 20, 5999-6005.

[103] O’Boyle, N.M.; Carr, M.; Greene, L.M.; Bergin, O.; Nathwani, S.M.; McCabe, T.; Llyod, D.G.; Zisterer, D.M.; Meegan, M.J. Synthesis and evaluation of azetidinone analogues of combretastatin A-4 as tubulin targeting agents. J. Med. Chem., 2010, 53, 8569-8584.

[104] Huber, S.K.; Werbovetz, K.A.; Obaza-Nutaitis, J.; Lehnert, E.K.; Macdonald, T.L. Tubulin binding of conformationally restricted bis-aryl compounds. Bioorg. Med. Chem. Lett., 1991, 1, 243-246.

[105] Kim, Y.; Nam, N.H.; You, Y.J.; Ahn, B.Z. Synthesis and Cytotoxicity of 3,4-Diaryl-2(5H)-furanones. Bioorg. Med. Chem. Lett., 2002, 12, 719-722.

[106] Nguyen, T.L.; McGrath, C.; Hermone, A.R.; Burnett, J.C.; Zaharevitz, D.W.; Day, B.W.; Wipf, P.; Hamel, E.; Gussio, R. A common pharmacophore for a diverse set of colchicine site inhibitors using a structure-based approach. J. Med. Chem., 2005, 48, 6107-6116.

[107] Romagnoli, R.; Baraldi, P.G.; Carrion, M.D.; Cruz-Lopez, O.; Tolomeo, M.; Grimaudo, S.; DiChristina, A.; Pipitone, M.R.; Balzarini, J.; Brancale, A.; Hamel, E. Substituted 2-(3',4',5'-trimethoxybenzoyl)-benzo[b]thiophene derivatives as potent tubulin polymerization inhibitors. Bioorg. Med. Chem., 2010, 18, 5114-5122.

[108] Odlo, K.; Hentzen, J.; Fournier dit Chabert, J.; Ducki, S.; Gani, O.A.; Sylte, I.; Skrede, M.; Florenes, V.A.; Hansen, T.V. 1,5-Disubstituted 1,2,3-triazoles as cis-restricted analogues of combretastatin A-4: Synthesis, molecular modeling and evaluation as cytotoxic agents and inhibitors of tubulin. Bioorg. Med. Chem., 2008, 16, 4829-4838.

[109] Soussi, M.A.; Aprile, S.; Messaoudi, S.; Provot, O.; Del Grosso, E.; Bignon, J.; Dubois, J.; Brion, J.D.; Grosa, G.; Alami, M. The metabolic fate of isocombretastatin A-4 in human liver microsomes: identification, synthesis and biological evaluation of metabolites. ChemMedChem, 2011, 6, 1781-1788.

[110] Unpublished results. 
[111] Réjiba, S.; Reddy, L.H. ; Bigand, C. ; Parmentier, C. ; Hajri, A. Squalenoyl gemcitabine nanomedicine overcomes the low efficacy of gemcitabine therapy in pancreatic cancer. Nanomedicine, 2011, 7, 841-849.

[112] Reddy, L.H. ; Khoury, H. ; Deroussent, A.; Ferreira, H.; Dubernet, C.; Declèves, X.; Besnard, M.; Chacun, H.; LepêtreMouehli, S.; Desmaële, D. ; Rousseau, B.; Laugier, C. ; Cintrat, J.C. ; Vassal, G. ; Couvreur, P. Squalenoylation favorably modifies the in vivo pharmacokinetics and biodistribution of gemcitabine in mice. Drug Metab. Dispos., 2008, $36,1570-1577$. 